\title{
Development of a Permeability Formula for Tight and Shale Gas Reservoirs Based on Advanced High-Precision Lab Measurement Techniques
}

\author{
Paulina Krakowska-Madejska ${ }^{1, *(\mathbb{D})}$, Edyta Puskarczyk ${ }^{1}{ }^{\circledR}$, Magdalena Habrat ${ }^{1}$, Paweł Madejski ${ }^{2} \mathbb{D}$, \\ Marek Dohnalik ${ }^{3}$ and Mariusz Jędrychowski ${ }^{4}$ \\ 1 Faculty of Geology, Geophysics and Environmental Protection, AGH University of Science and Technology, \\ Al. Mickiewicza 30, 30-059 Krakow, Poland; puskar@agh.edu.pl (E.P.); mladniak@agh.edu.pl (M.H.) \\ 2 Faculty of Mechanical Engineering and Robotics, AGH University of Science and Technology, \\ Al. Mickiewicza 30, 30-059 Krakow, Poland; madejski@agh.edu.pl \\ 3 Oil and Gas Institute-National Research Institute, Lubicz 25A, 31-503 Krakow, Poland; dohnalik@inig.pl \\ 4 Faculty of Physics and Applied Computer Science, AGH University of Science and Technology, \\ Al. Mickiewicza 30, 30-059 Krakow, Poland; mariusz.jedrychowski@fis.agh.edu.pl \\ * Correspondence: krakow@agh.edu.pl; Tel.: +48-12-617-32-30
}

check for updates

Citation: Krakowska-Madejska, P.; Puskarczyk, E.; Habrat, M.; Madejski, P.; Dohnalik, M.; Jẹdrychowski, M. Development of a Permeability Formula for Tight and Shale Gas Reservoirs Based on Advanced High-Precision Lab Measurement Techniques. Energies 2021, 14, 2628. https://doi.org/ $10.3390 /$ en14092628

Academic Editor: José A. Torres

Received: 9 February 2021

Accepted: 30 April 2021

Published: 4 May 2021

Publisher's Note: MDPI stays neutral with regard to jurisdictional claims in published maps and institutional affiliations.

Copyright: (C) 2021 by the authors. Licensee MDPI, Basel, Switzerland. This article is an open access article distributed under the terms and conditions of the Creative Commons Attribution (CC BY) license (https:// creativecommons.org/licenses/by/ $4.0 /)$

\begin{abstract}
Computed X-ray tomography (CT), together with pulse and pressure decay permeability methods were used to evaluate a formula for absolute reservoir permeability. For this reason, 62 core samples representing geological material of tight, gas-bearing sandstones, mudstones, limestones, and dolostones were studied. Samples were divided into two groups with lower and higher permeability values. Images of the pore space were processed and interpreted to obtain geometrical parameters of the objects (pores, microfractures) with $0.5 \times 0.5 \times 0.5 \mu^{3}$ voxel size. Statistical methods, which included basic statistical analysis, linear regression, and multiple linear regression analysis, were combined to evaluate the formula for absolute permeability. It appeared that the following parameters: Feret Breadth/Volume, Flatness/Anisotropy, Feret Max/Flatness, moments of inertia around middle principal axis I2/around longest principal axis I3, Anisotropy/Flatness, Flatness / Anisotropy provided the best results. The presented formula was obtained for a large set of data and is based only on the geometric parameters of the pore space. The novelty of the work is connected with the estimation of absolute permeability using only data from the CT method for tight rocks.
\end{abstract}

Keywords: permeability; computed X-ray tomography; shale gas; tight rocks; geoscience; multiple linear regression

\section{Introduction}

New methods to evaluate the absolute permeability in low-porosity and low-permeability rocks are a challenge for the petroleum industry [1-4]. Kozeny presented one of the most useful relations among permeability, porosity, and specific surface area, assuming that the rock consists of a set of straight capillary tubes (the porosity component) and cement (the skeleton component) [5]. One of the equations used for permeability estimation is built based on the porosity and specific surface area of a porous material Svgr (the total area exposed within the pore space per unit of grain volume). The parameter, which is called the specific surface area of a porous material Svgr, can be obtained from the specific surface area per unit of pore volume Svp, which is calculated from capillary data or petrographic image analysis. The Kozeny equation is reasonable for use when the pore space structure is similar to the set of straight capillary tubes, and the porosity is relatively high. Usually, these requirements cannot be satisfied, especially in tight rocks [6-10]. Valuable studies are conducted regarding the integrated production logging tool for permeability measurements in multi-layered fractured reservoirs [11] and the subject of the enhanced oil recovery and 
various aspects of unconventional reservoirs specificity [12-18]. Nevertheless, the Kozeny equation is still used to evaluate absolute permeability in both the standard and modified forms $[19,20]$. Assessment of absolute permeability will always be a top problem to solve because it is a key parameter in evaluating fluid flow abilities in reservoirs [21,22].

Currently, computed X-ray tomography (CT) is a technique that enables the details of the internal structure of porous materials to be determined [23-28]. The results of CT measurements can be used in fluid flow simulations through the pore space and permeability estimation [29-32] and in rock heat transfer modelling [33,34]. Moreover, CT provides information at the nano, micro (pore space analysis), and macro scales (medical CT of cores). Many studies consider CT scanning a useful method for analyzing small samples to obtain information about the pore space and standard cores (medical CT). Permeability measurements are expensive and often destroy the material. Hence, research has concentrated on searching for an equation to initially estimate permeability, subsequently determining the place locations of plug probing (places of permeability variation) and, finally, minimizing the cost of laboratory measurements. This equation will not replace laboratory measurements but can help to estimate permeability in the core profile, where low porosity and low permeability rocks are present.

The computed X-ray tomography, pressure and pulse decay permeability laboratory method combined with the statistical method of multiple linear regression are used to search for a formula to estimate the absolute permeability in tight rocks. Statistical methods such as multiple linear regression, neural networks, principal component or cluster analysis are helpful in geological materials analysis. Kayabasi et al. [35] used the pioneer study in estimating the rock mass permeability by non-linear multiple regression analysis and Adaptive Neuro-Fuzzy Inference System. Furthermore, Habib et al. [36] proposed a practical equation that consists of different statistical and fractal characteristics of fracture patterns using multivariate regression analysis to estimate modelled permeabilities. This approach represents the scientific background for the similar future analysis. Puskarczyk et al. [37] tested principal component analysis and cluster analysis in gas-saturated horizons identification using well logs. Investigations between the lithology combination index and fracture porosity using machine learning, regression analysis, and weighting methods are presented by Zhang et al. in the [38]. Moreover, the machine learning technique is also presented in Zhang et al. [39] for permeability estimations of isolated channel sands and in Sudakov et al. [40] for prediction of permeability in 3D computed X-ray tomography images of rock samples, as well as in Erofeev et al. [41] for estimating the alteration of porosity and permeability without conducting the measurement in the laboratory. Neural networks were used by Roshani et al. [42] for determining the density and velocity for single-phase flow and by $\mathrm{Wu}$ et al. [43] in predicting permeability from the pore-scale images. The question is, what is the advantage of the statistical method compared to other methods? Definitely, statistical methods allow finding and understanding any patterns within the data and dealing with the large number of data $[44,45]$.

The novelty of this study was the investigation of the influence of several geometrical parameters of pores from computed X-ray tomography on the logarithm of permeability simultaneously. Multilinear regression analysis gave that opportunity. Moreover, the usefulness of all CT geometrical parameters of pores was carefully checked in efficient permeability determination. There is a linear relationship between the porosity and the logarithm of permeability in most reservoirs, so it was assumed, that pore-related parameters, as CT geometrical parameters of the pore space can give also a result.

First, computed X-ray tomography data are described in this paper with qualitative and quantitative interpretations of the pore space of 62 tight rock samples. The laboratory results from the pulse and pressure decay permeability methods are considered with reference to the porosity values. Next, a basic statistical analysis of the quantitative, geometrical parameters of the rock pore space is presented to show the relationships among the parameters. Finally, multiple linear regression analysis is performed to determine a formula for the absolute permeability estimation in tight Paleozoic rocks based only on 
computed X-ray tomography data, which yields consistent results with the laboratory permeability measurements.

The study was focused on determining the absolute permeability for the tight Paleozoic gas-saturated rocks, no slip-flow of fluid molecules was considered [46-48]. Moreover, the effect of organic matter presence in determining the permeability of tight rocks is important but not taken up in the study $[49,50]$. Anisotropic permeability, which is essential for compacted tight rocks, cannot be predicted using the presented formula [51,52].

\section{Materials and Methods}

\subsection{Material Description}

The geological material consists of 62 Paleozoic core samples taken from wells in Poland (East Europe), which were probed from a depth greater than $2000 \mathrm{~m}$ of the present deposition. Samples are gas-bearing, tight sandstones, mudstones, limestones, and dolostones, representing shale and tight gas reservoirs. All the samples satisfy the condition of low permeability (absolute permeability below $1 \mathrm{mD}$ ). Moreover, 24 samples were cored from wells from the Lublin Synclinorium, 14 from the Peri-Baltic Syneclise, 12 from Polish Lowlands, four from the Warsaw Synclinorium, and two each from the Pomeranian Anticlinorium, Pomeranian Synclinorium, Holly-Cross Anticlinorium, and Nida Basin. The age, geological unit, and lithology of each sample are presented in the Appendix A (Table A1). The samples were deliberately collected from different lithologies, from clastics to carbonates, to create a relatively general equation for tight rocks using computed X-ray tomography parameters. Plugs for the laboratory measurements were probed horizontally to the beds. Figure 1 presents the dependence of absolute permeability on total porosity from CT. According to CT, the most numerous group of samples is placed below $0.001 \mathrm{mD}$ in permeability and has a wide range of total porosity. A slight increase in absolute permeability with total porosity is observed in the group of points characterized by absolute permeability values of greater than $0.001 \mathrm{mD}$. The limitation in the data is connected with the very low porosity value in some samples. It is connected with the samples specificity, which belongs to the group of tight gas reservoirs.

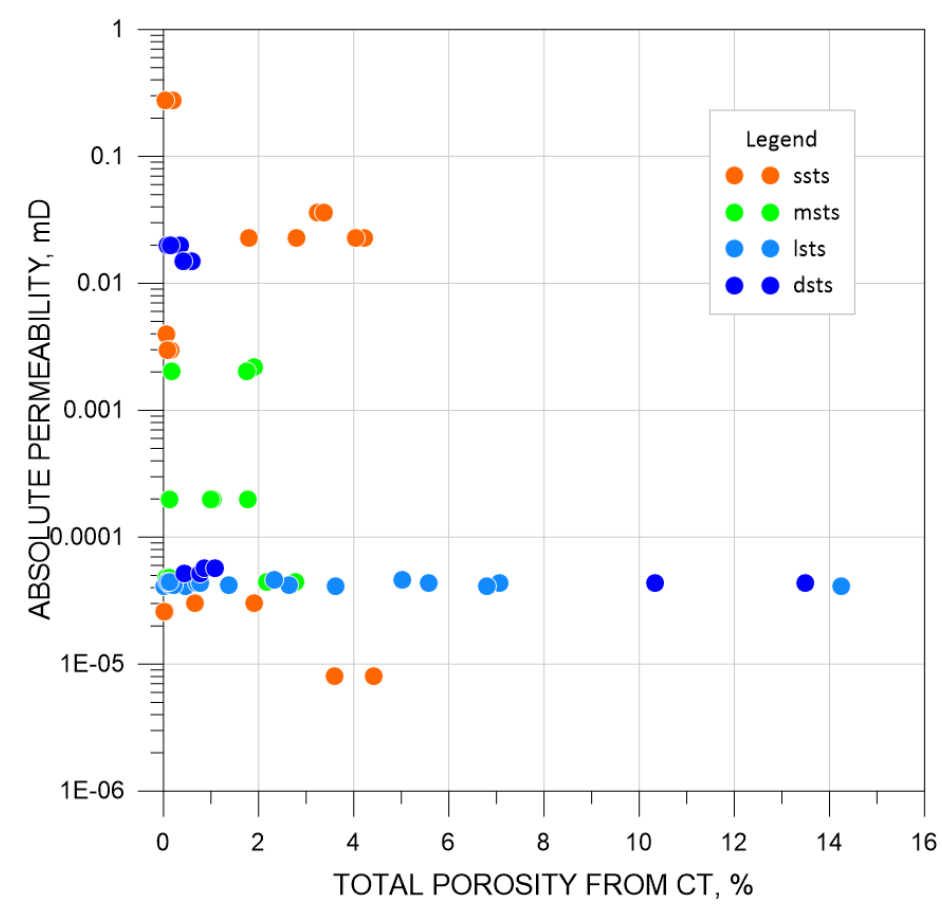

Figure 1. Dependence of absolute permeability from pressure and pulse-decay method on total porosity from CT for all analyzed samples. Symbols: ssts—sandstones, msts—mudstones, lstslimestones, dsts-dolostones. 
The pore space structures of exemplary samples of tight sandstone (sample 20, CT porosity $-1.91 \%$, absolute permeability-30 nD), mudstone (sample 27, CT porosity$1.01 \%$, absolute permeability $-190 \mathrm{nD}$ ), limestone (sample $41, \mathrm{CT}$ porosity-7.06\%, absolute permeability-40 $\mathrm{nD}$ ) and dolostones (sample $61, \mathrm{CT}$ porosity-13.4\%, absolute permeability- $40 \mathrm{nD}$ ) are presented in Figures 2-5. Figures 2-5 visualize only the selected fragment of the pore space. The pores are quite evenly spaced in all of these samples. Visible thin layers can sometimes be observed with the increasing density of objects in mudstones. The total porosity according to CT was approximately $0.8-14 \%$, while the absolute permeability was from approximately $0.008 \mathrm{nD}$ to $0.27 \mathrm{mD}$ for all samples.

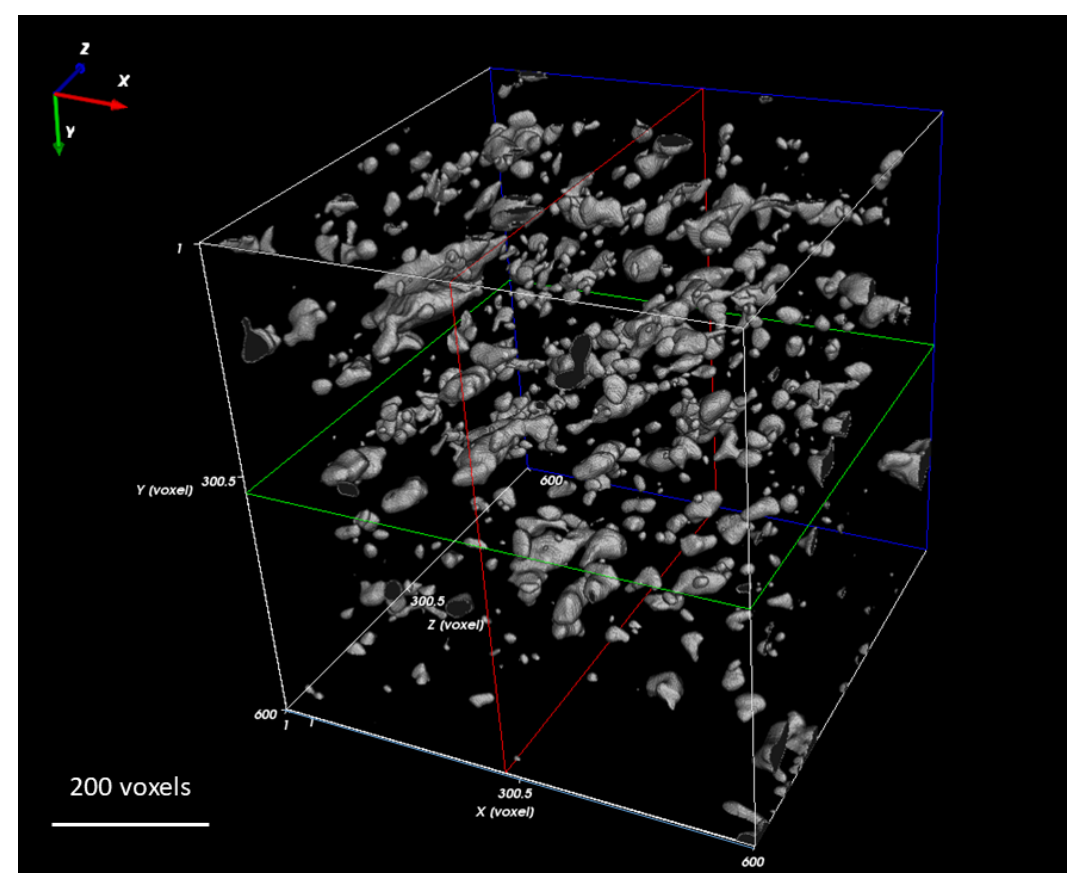

Figure 2. Pore space of tight sandstone (sample 20), poROSE software.

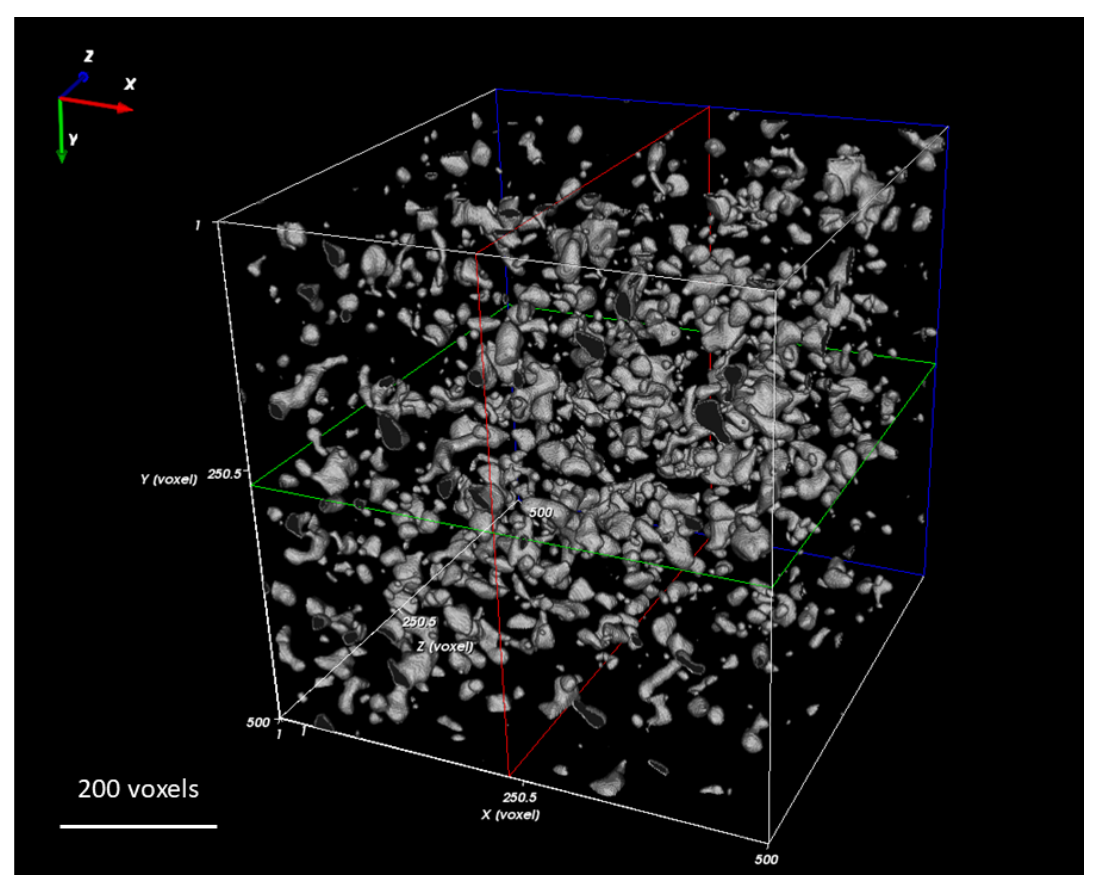

Figure 3. Pore space of mudstone (sample 27), poROSE software. 


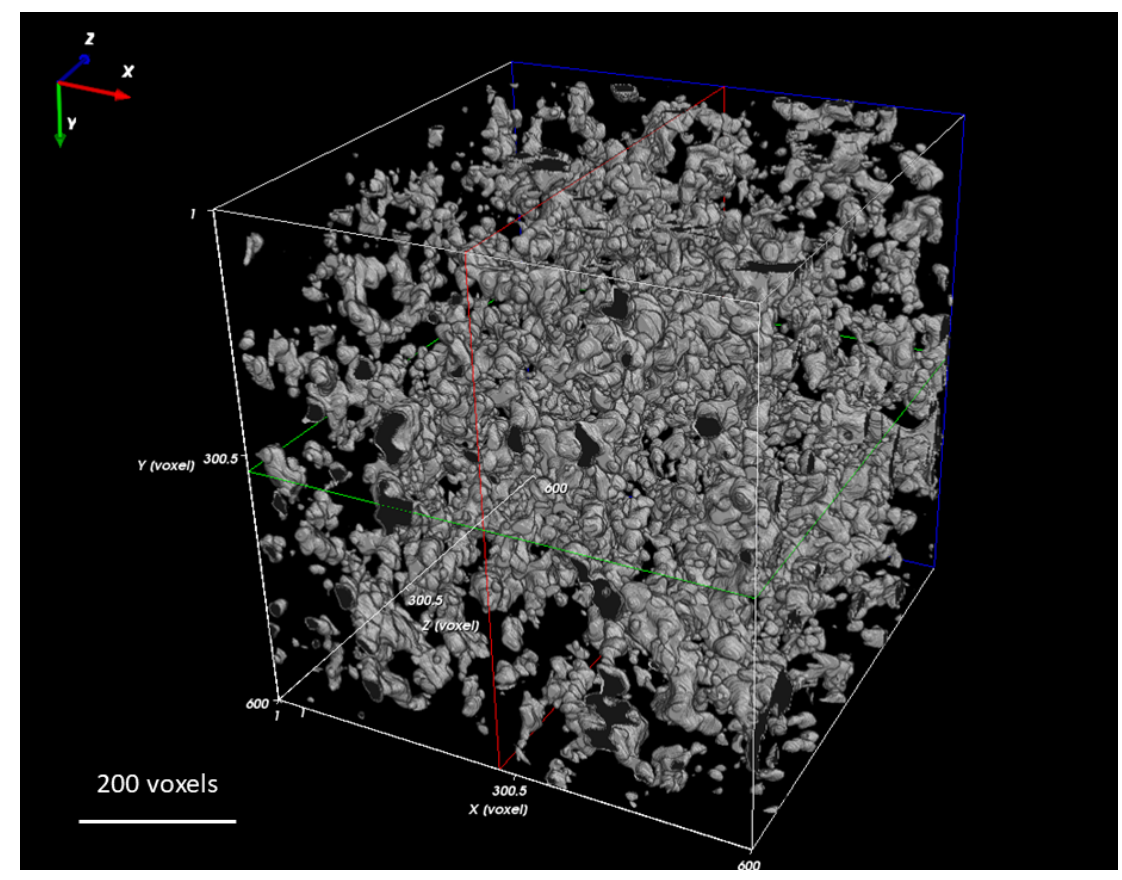

Figure 4. Pore space of tight limestone (sample 41), poROSE software.

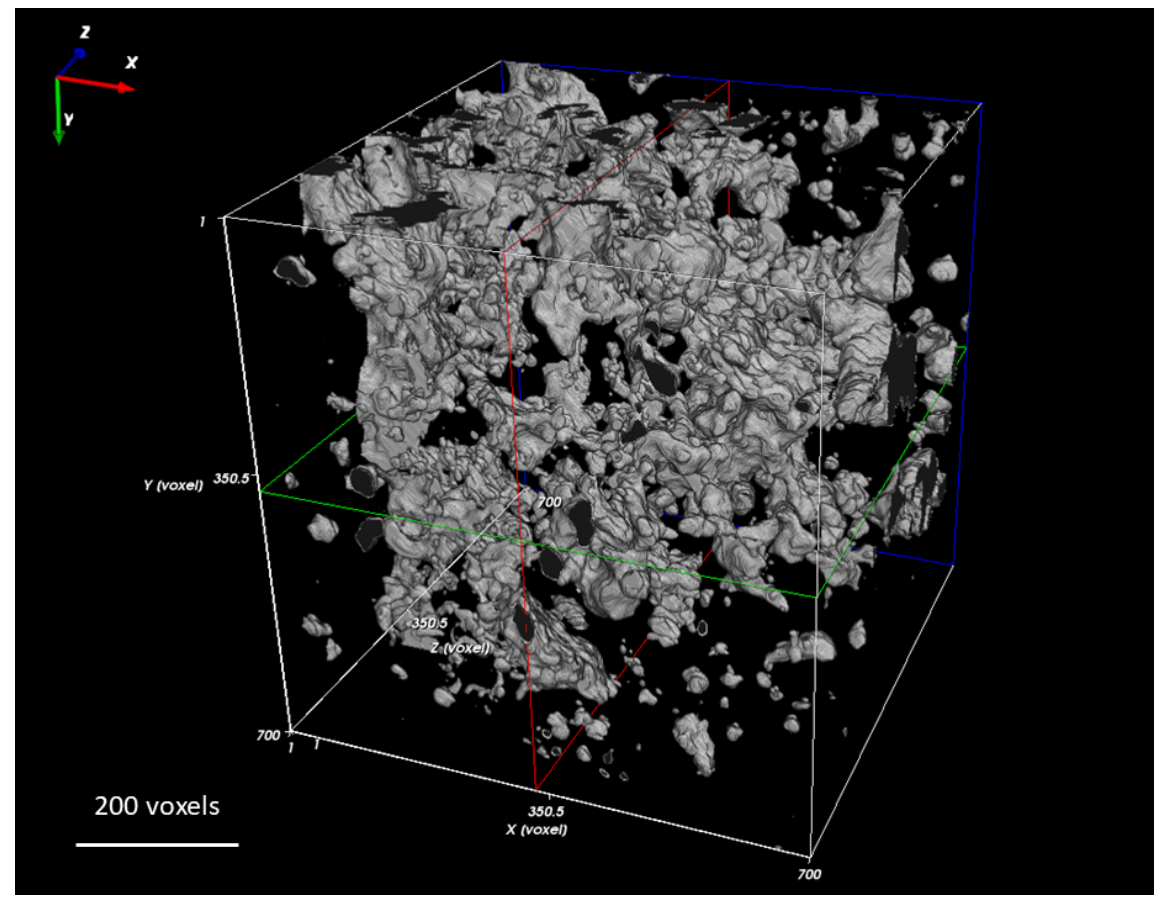

Figure 5. Pore space of tight dolostones (sample 61), poROSE software.

Figure 6 presents box plots: the median (square), upper and lower quartiles (box), and minimum and maximum (lines) of median values from the pore parameters in each sample were collected in each lithology group. The maximum Feret diameter (caliper diameter, the distance between the two defined parallel planes) is higher than the other parameters because it is calculated in the object view (projection on the plane) for the highest detected diameter. Lower diameters characterize only dolostones. The average thickness (the diameter) in the sandstone, mudstone, limestone, and dolostone groups is $2.95 \mu \mathrm{m}, 2.82 \mu \mathrm{m}, 2.33 \mu \mathrm{m}$, and $1.77 \mu \mathrm{m}$, respectively. For an Equivalent diameter, the minimum and maximum Feret diameters were assumed to reach higher values. The 
analysis focused on objects that were detected by CT and effectively participated in the fluid flow.

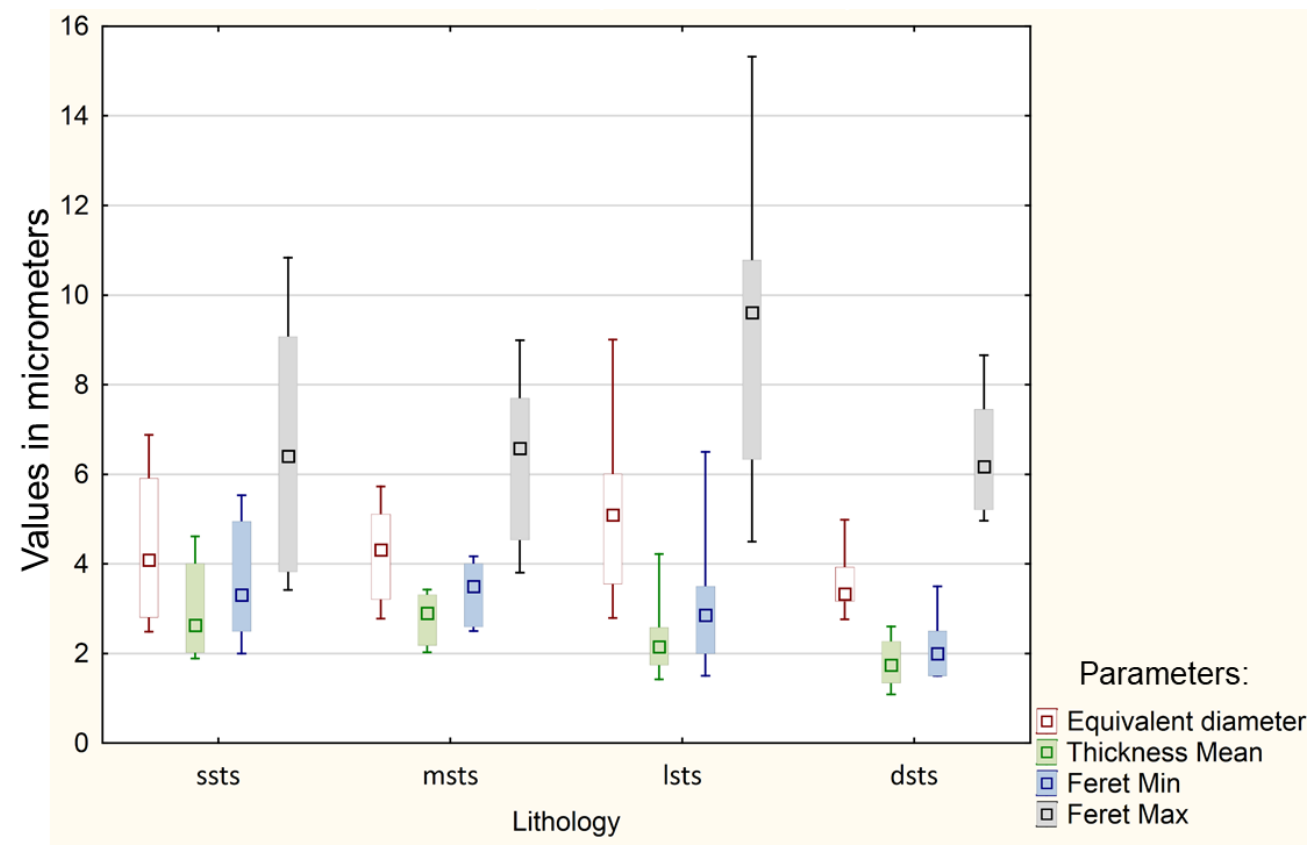

Figure 6. Geometric parameters in the form of diameters (Equivalent dimeter, Thickness mean, Feret minimum diameterFeret Min, Feret maximum diameter-Feret Max) in 4 lithology groups. Symbols as in Figure 1.

The pore size distribution is presented in Figure 7 in the form of the mean thickness in micrometers for the selected samples: 20, 27, 41, and 61 . The largest number of objects is detected in limestone, followed by dolostone, while the smallest number of objects is detected in mudstone. Limestone has more pores than dolostone but is characterized by smaller pore size.

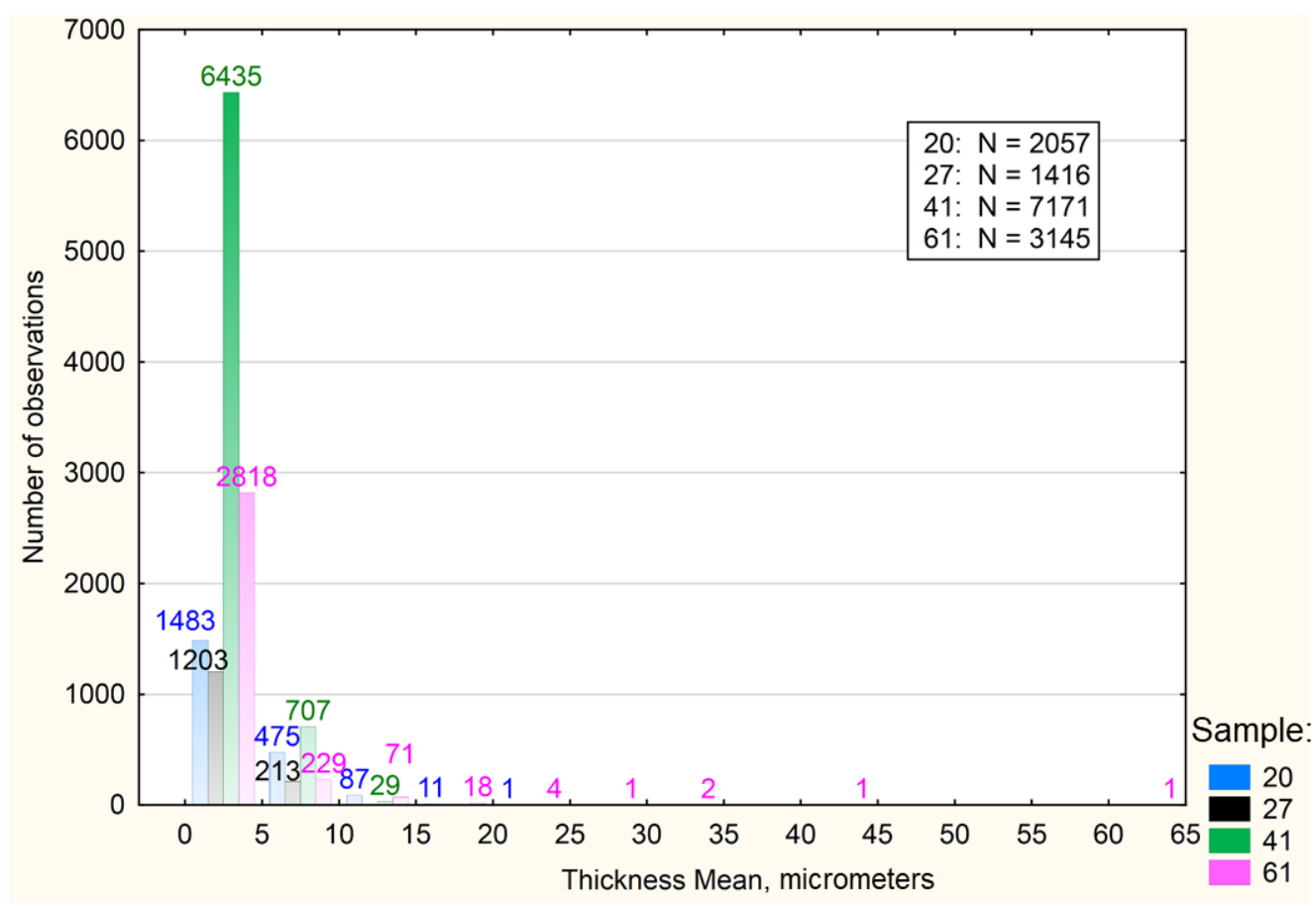

Figure 7. Pore size distribution reflected by thickness mean. 


\subsection{Mercury Injection Capillary Pressure Method}

Additionally, mercury injection capillary pressure (MICP) data in the form of the pore size distribution are presented for the selected rock samples. The MICP data were collected using an AutoPore IV 9500 (Micromeritics, Norcross, GA, USA) with a maximum working pressure of $60,000 \mathrm{psi}$ and a minimum pressure of the atmospheric (ambient) pressure. Pores in the range of $0.003-300 \mu \mathrm{m}$ in diameter are penetrated by mercury. The samples were placed in a holder, which was filled with mercury (vacuum conditions). The MICP data were corrected for the closure effect [53]. The closure effect is an error in measurement caused by the rough outer surface of the tested sample, which results in an apparent increase in porosity based on a mercury porosimetry of $0.1-0.5 \%$. The closure correction is significant for samples with low porosity. It should be used based on the volume of the injected mercury curve compared to the pressure from the initial measurement phase. The ink-bottle effect was not considered [54,55]. The MICP experiment was not successfully conducted for several samples because the samples were destroyed at very high injection pressures. The pore-fracture or fracture system was mainly detected in the analyzed samples considering the shape of the graphs (Figure $8 \mathrm{a}-\mathrm{d}$ ). The pore-fracture system forms a continuous shape with sharp peaks (e.g., Figure $8 \mathrm{a}$, the section from 0.01 to $1 \mu \mathrm{m}$ ), while the fracture system forms separate peaks (e.g., Figure 8a, the peak centered at $3 \mu \mathrm{m}$ ). The pore size distribution from the MICP and CT data is presented for the sandstone, mudstone, limestone, and dolostone groups (Figure 8a-d). The MICP data cover a wider range of pore diameters than the $\mathrm{CT}$ data. In the analysis, the objects recognized in $\mathrm{CT}$ were greater than $0.5 \times 0.5 \times 0.5 \mathrm{\mu m}^{3}$ in volume. All the graphs show a comparison of the detected pore sizes. For the CT data, the Y-axis presents the number of measured objects and recognized in a specific volume, which explains the difference in the number of observations among the samples. The MICP data for higher diameters showed a larger mercury volume injected into the objects, while $\mathrm{CT}$ did not recognize any objects. The pore size distribution from the $\mathrm{CT}$ data corresponds with that from the MICP data above the specific pore diameter that was recognized by the CT and limited by the CT scanner resolution. A part of the information about the microporosity can be missed because of the CT limits in resolution. As a non-invasive method, CT complements the information obtained from MICP, especially for the observed large pore diameters that did not coincide with the CT results. CT can be used to verify and extend the closure correction.

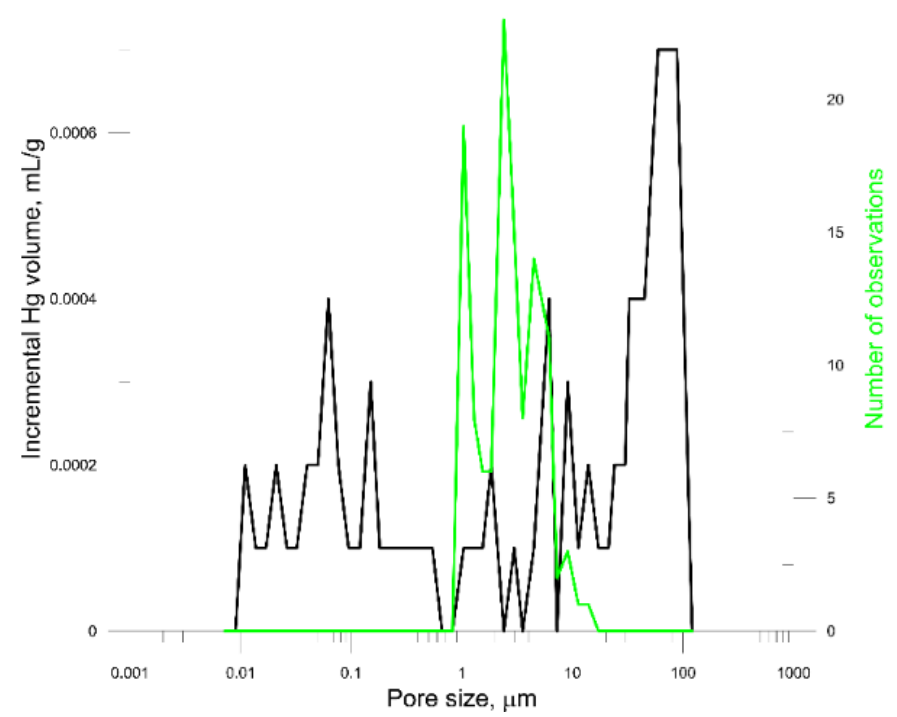

(a)

Figure 8. Cont. 


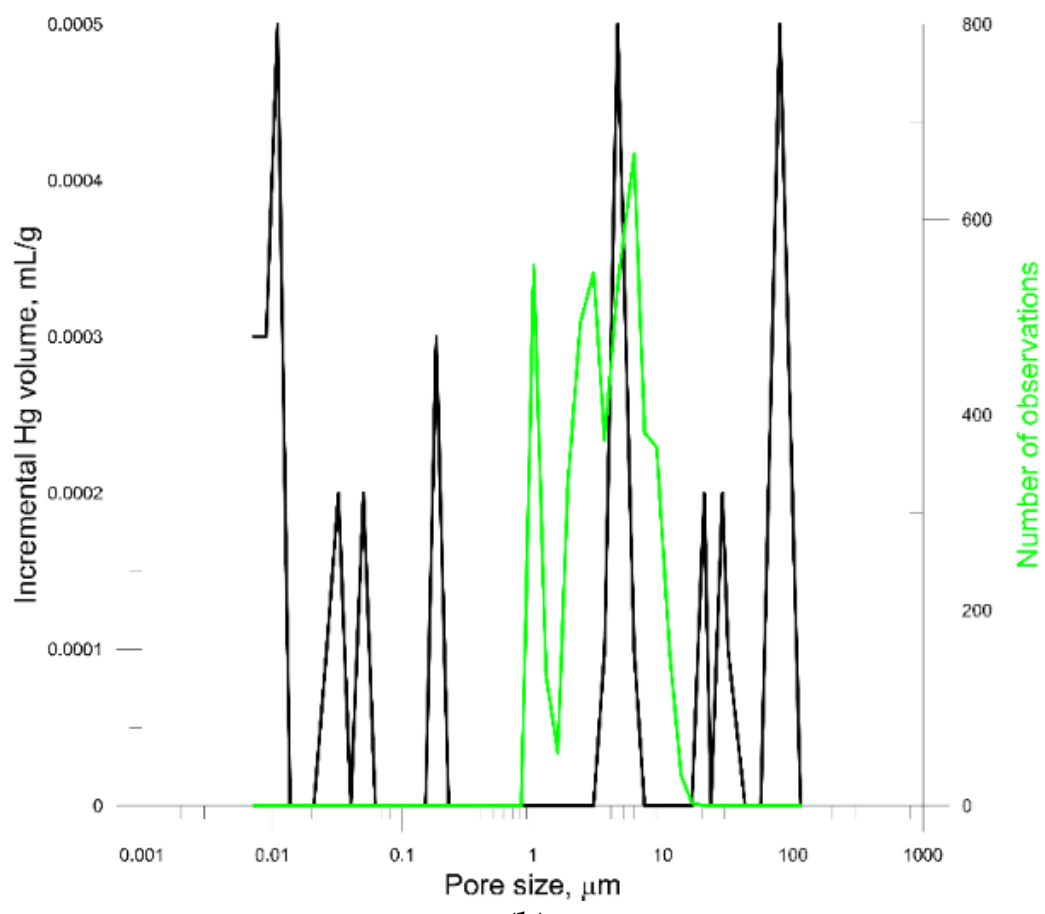

0.004

(b)

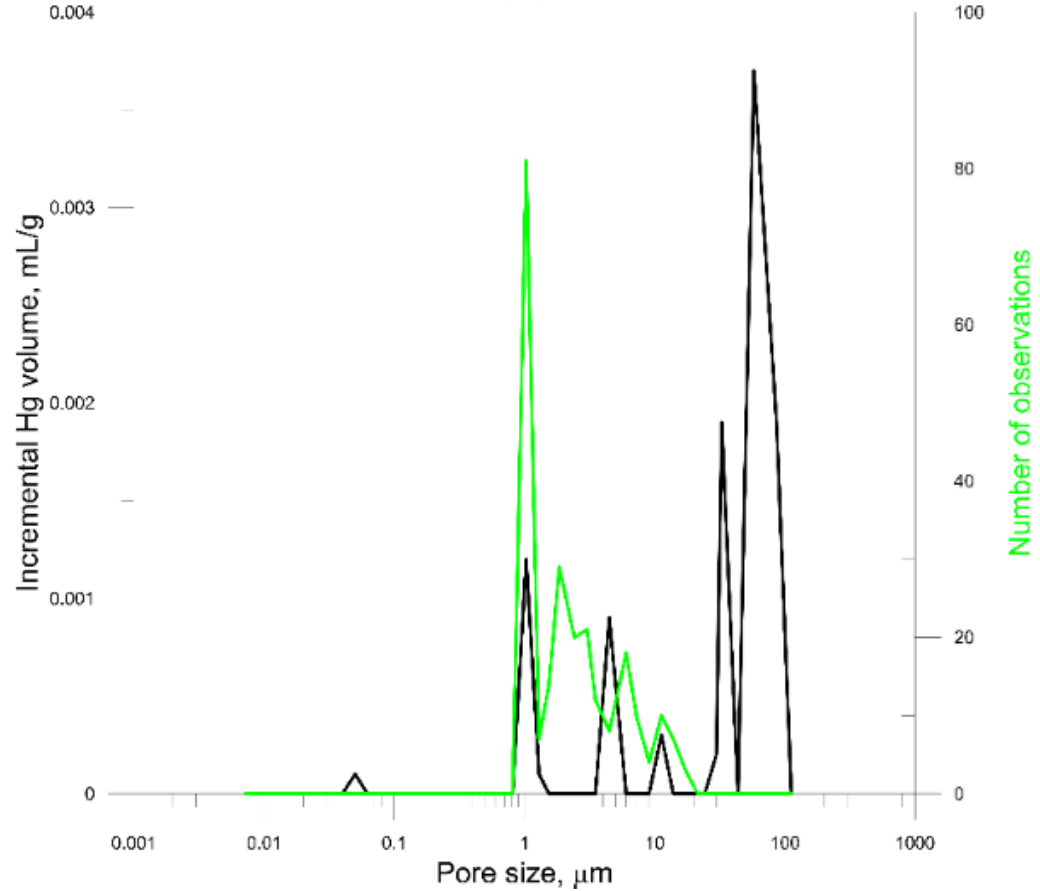

(c)

Figure 8. Cont. 


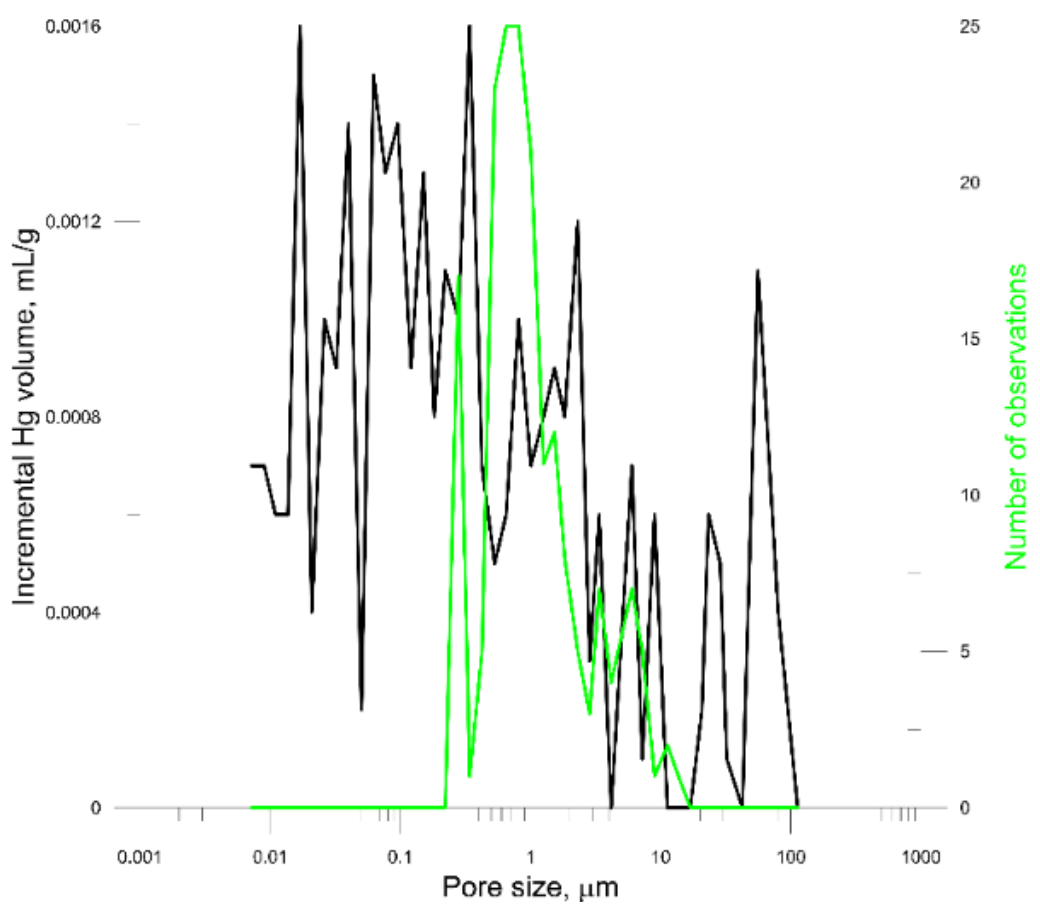

(d)

Figure 8. (a) Pore size distribution from MICP (black) and CT (green) for exemplary sandstone sample 16. (b) Pore size distribution from MICP (black) and CT (green) for exemplary mudstone sample 31. (c) Pore size distribution from MICP (black) and CT (green) for exemplary limestone sample 46. (d) Pore size distribution from MICP (black) and CT (green) for exemplary dolostone sample 50 .

Several experimental and computational methods were used to evaluate the new formula for absolute permeability in tight Paleozoic rocks: computed X-ray tomography (CT), pulse and pressure decay permeability method, and multiple linear regression analysis.

\subsection{Computed X-ray Tomography Method}

Computed X-ray tomography is a technique that enables the recognition of the pore space in 3D [56]. The physical background of this method is connected with the X-ray attenuation, which is a function of X-ray energy and material density [57-60]. The CT measurement is used in the petroleum industry to perform structure analysis at the macro scale (medical CT) and determine the pore space distribution at the microscale (high-resolution CT), which is extremely important in hydrocarbon prospecting and exploration [61-63]. CT was performed in the Laboratory of Micro and Nano Tomography at the Faculty of Physics and Computer Sciences (AGH UST in Krakow, Poland) using a Nanotom S 180n Sensing \& Inspection Technologies instrument (General Electric, Boston, MA, USA). The technical parameters of CT are presented in Table 1. Core samples for the CT measurements were investigated in "as received" state without analyzing the fluid properties. The information about the gas saturation was provided by the contractor.

$3 \mathrm{D}$ qualitative and quantitative analyses of $\mathrm{CT}$ images were performed in the poROSE software (poROus materials examination SoftwarE), which is a platform used for 2D and $3 \mathrm{D}$ analyses in both academia and industry $[66,67]$. The software can be run at the Microsoft Windows operating system. It allows for object size classification regarding volume (voxels), object parametrization (volumes, diameters, shape), tortuosity calculation using different methods, shape factors determination, mean intercept length analysis, and full skeleton analysis. The license is provided after licensing agreement, scientific or commercial. 
Table 1. Specification of Nanotom S 180n General Electric Sensing \& Inspection Technologies, image reconstruction, and processing description.

\begin{tabular}{ll}
\hline Element/Process & Description \\
\hline X-ray tube & $57-\mathrm{W}$, max working voltage $180 \mathrm{kV}$ \\
Detector & Hamamatsu 2300 $\times 2300$ \\
Voxel size & $($ Ham C 7942CA-02) \\
Reconstruction & $0.5 \times 0.5 \times 0.5 \mu \mathrm{m}^{3}$ \\
Image processing & Feldkamp algorithm [64] \\
\hline
\end{tabular}

The calculated quantitative parameters include the volume and shape of pores and microfractures. Permeability mainly depends on the effective porosity, grain size, shape, and distribution. Grain shape, sorting, and packing also affects the pore and microfracture structures, which are extremely important for conducting fluids through interconnected pores. The calculated parameters based on the CT images of all 62 samples are presented in Table A2 in the Appendix A).

A combination of the quotients of the samples was defined based on the calculated parameters, e.g., I3/I1. In summary, 291 parameters were obtained from the CT images to analyze absolute permeability.

One of the CT parameters-Anisotropy is connected with the deviation of the pore's shape from the sphere, not with the anisotropic permeability. Surface Area parameter is the surface area of the pore that are directly adjacent to the object's surroundings and can be related to the hydraulic radius concept and Kozeny concept in determining the permeability but is not reflecting the features of capillary tubes, what is a disadvantage [68].

The calculation of 49 parameters from the 3D CT images is time-consuming. Nevertheless, 3D CT images are the input for porosity and pore size calculations. Geometrical parameters presented in the paper, together with porosity, are available in commercial and open source softwares. Having binarized 3D image of a pore space, it is feasible to calculate all geometrical parameters in one operation time.

\subsection{Pulse and Pressure Decay Permeability Method}

The key parameter in the pulse and pressure decay permeability method is the absolute permeability determined from laboratory measurements of core samples. Pulse and pressure decay permeability measurements were performed at the Terra Tek Schlumberger Reservoir Laboratory (Salt Lake City, UT, USA) [69,70]. The pressure decay permeability measurement was conducted on mudstone samples, and the remaining samples were investigated using the pulse decay permeability measurement. The pressure decay method was performed on crushed material with no overburden stress using helium gas, while the pulse decay method was performed on core plugs under a hydrostatic confining pressure with nitrogen as the working fluid.

\subsection{Multiple Linear Regression Analysis}

Multiple linear regression (MLR) is included in statistical modelling to estimate the relationships between several different independent variables and one dependent variable [71,72]:

$$
Y=b_{0}+b_{1} X_{1}+b_{2} X_{2}+\ldots+b_{p} X_{p}
$$

where: $Y$-predicted value (dependent variable); $X_{1}, X_{2}, \ldots, X_{p}$-independent variable; $p$-number of independent variables; $b_{0}, b_{1}, \ldots, b_{p}$ - estimated regression coefficients.

MLR fits the linear equation to the analyzed data points. In the evaluation of the permeability equation, it was necessary to consider both porosity as a key parameter and other pore shape parameters. Thus, multiple linear regression was used to retrieve information about the permeability relationships with other geometrical parameters of the pore space. The dependent variable in MLR analysis is the absolute permeability from 
laboratory measurements (the results of the pulse or pressure decay methods on the core samples), while the independent variables are the geometrical parameters of the pore space, which were calculated based on the CT images of the core samples. The split in the data set is $70 \%$ calibration, $15 \%$ validation, and $15 \%$ testing according to typical traditional statistics or machine learning. For the analyzed data, it was decided to present all 62 samples in the article that were included in the calibration set due to a large number of tested parameters and the relatively small data set. Validation and testing were performed on subsamples (a cube was randomly cut from the 3D images and treated as a separate sample) to check the correctness of the multiple regression coefficients. The application of the obtained multiple regression equations to the validation set confirmed the correctness of the formula. Due to the specifics of the analyzed samples (low porosity and low permeability), the obtained relation can only be generalized for rocks with similar reservoir parameters and a similar pore space structure.

For low-porosity and low-permeability rocks, the scatter of the porosity and permeability values in the samples is quite large, and blind measurements are fraught with errors. We are not sure of the exact range of value in which we operated. The relative error for low-porosity rocks (approx. 2.5-3.5\% of total porosity) is higher than for conventional rocks (approx. 25-35\% of total porosity). Suppose the porosity in the rock differs by $0.1 \%$ porosity as a result of poor measurement. In that case, the relative error is $0.3-0.4 \%$ in conventional rocks and as much as 3-4\% in low-porosity rocks. Therefore, using any formula such as those presented in the paper increases the accuracy and probability of determining the correct permeability value. This process is especially important when determining porosity and permeability based on well logging, which is calibrated to the results of laboratory tests and increases the chance of estimating a similar permeability in the reservoir.

\subsection{Stages of the Analysis}

The stages of analysis begin with the CT parameter calculation and end with the multiple linear regression analysis:

(1) calculate the geometrical parameters for each object (pore, microfracture) in each sample (parameters in Table 2 and their quotients) and the porosity;

(2) quality check (check the value correctness in the range, e.g., 0-1, and interpretable values, i.e., whether the value has a physical meaning) the parameters for each of the 62 samples;

(3) calculate the statistics: maximum, minimum, average, standard deviation, median, 10th percentile, 90th percentile, lower quartile, and upper quartile based on the parameters from all the objects (pores, microfractures) in each sample, e.g., calculate the average thickness (parameter) of all the objects in each sample (finally, 1 sample corresponds to 1 value of a parameter);

(4) extract the parameters for the largest object in each of the 62 samples;

(5) construct the data set: one data set consists of a particular statistical parameter, which is calculated for each sample and all the available parameters from CT, e.g., the data set of the average values of each sample and all the parameters calculated from CT;

(6) analyze the relationships between the absolute permeability from laboratory measurements and the 291 parameters from the CT images (based on their correlation coefficients); only the parameter that correlates with the logarithm of absolute permeability with a correlation coefficient above \pm 0.5 is considered;

(7) construct a data set from the parameters that showed a linear relationship (correlate) with the logarithm of permeability (reject insignificant parameters);

(8) perform multiple linear regression analysis on the data set from item 7 (parameters that correlate with the logarithm of absolute permeability). 
Table 2. List of parameters used in building the linear relationship with the logarithm of absolute permeability.

\begin{tabular}{|c|c|}
\hline Data Set & Parameter \\
\hline The largest object values & $\begin{array}{l}\text { Thickness Mean, } \\
\text { Volume/Surface Area, } \\
\text { Surface Area/Volume, } \\
\text { Feret Breadth/Volume, } \\
\text { Anisotropy/Thickness Max, } \\
\text { Elongation/Thickness Max, } \\
\text { Elongation/Thickness Mean }\end{array}$ \\
\hline Median values & Feret Breadth/Feret Max \\
\hline Maximum values & $\begin{array}{l}\text { Thickness Max, } \\
\text { Thickness Max/Elongation, } \\
\text { Thickness Mean/Elongation, } \\
\text { Thickness Mean/Feret Shape }\end{array}$ \\
\hline Upper quartile values & $\begin{array}{l}\text { Flatness, } \\
\text { Equivalent Diameter/Feret Max, } \\
\text { Thickness Mean/Feret Max, } \\
\text { Flatness/Anisotropy, } \\
\text { Feret Breadth/Feret Max, } \\
\text { I3/I2 }\end{array}$ \\
\hline Lower quartile values & $\begin{array}{l}\text { Feret Max/Equivalent Diameter, } \\
\text { Anisotropy/Flatness, } \\
\text { Anisotropy/ShapeVA3D, } \\
\text { Feret Max/Flatness, } \\
\text { Feret Breadth/Flatness, } \\
\text { Feret Max/Feret Breadth, } \\
\text { I2/I3 }\end{array}$ \\
\hline Percentile 10 values & $\begin{array}{l}\text { Anisotropy, } \\
\text { Feret Max/Thickness Max, } \\
\text { Feret Max/Thickness Mean, } \\
\text { Anisotropy/Flatness, } \\
\text { Anisotropy/ShapeVA3D }\end{array}$ \\
\hline Percentile 90 values & $\begin{array}{l}\text { Flatness, } \\
\text { Sphericity, } \\
\text { Thickness Max/Thickness StD, } \\
\text { Thickness Mean/Thickness StD, } \\
\text { Elongation/Anisotropy, } \\
\text { Flatness/Anisotropy, } \\
\text { ShapeVA3D/Anisotropy, } \\
\text { Flatness/Feret Max, } \\
\text { Flatness/Feret Breadth, } \\
\text { Flatness/Feret Shape, } \\
\text { I3/I2 }\end{array}$ \\
\hline Standard deviation values & $\begin{array}{l}\text { Elongation/Thickness Max, } \\
\text { Elongation/Thickness Mean, } \\
\text { Thickness StD/Elongation, } \\
\text { Thickness StD/Feret Shape, } \\
\text { Elongation/Anisotropy, } \\
\text { Flatness/Anisotropy, } \\
\text { ShapeVA3D/Anisotropy, } \\
\text { Flatness/Feret Shape }\end{array}$ \\
\hline
\end{tabular}

Thus, 291 parameters from the CT images and the logarithm of the absolute permeability for the 62 core samples were collected in 11 data sets. Each data set consists of the maximum, minimum, average, standard deviation, median, 10th percentile, 90th percentile, lower quartile or upper quartile value of the parameters for each sample. The additional 
data set contains parameters for the largest object in each sample. An attempt was made to find formulas for absolute permeability using only the geometrical parameters of the pore space from CT data.

\section{Results and Discussion}

\subsection{Basic Analysis}

The geometrical parameters of the pore space for all 62 samples were checked considering the value reliability and being within the correct range. The basic parameters for the largest object in the sample are collected in the Appendix A (Table 1), which shows the variety of the data. The largest object is usually the most complicated structure because it potentially has highest effective porosity. The largest objects are not close to the shape of a ball (average Anisotropy approximately 0.64), are not flat (average Flatness approximately 0.44 ), are tortuous (average ShapeVa3D of approximately 0.38 ), and are more likely elongated (average Elongation approximately 0.85).

The basic analysis concentrated on searching for linear relationships between basic quantitative parameters from CT images and the logarithm of absolute permeability. Some of the parameters exhibited linear relationships with the logarithm of permeability and a normal distribution. There are not always perfect fits, but it does not exclude the multiple linear regression of the data.

\subsection{Linear Relationships between the Logarithm of Absolute Permeability and CT Parameters}

Figures 9-11 present histograms of the example quantitative geometrical parameters of the pore space: Sphericity, Flatness and Feret Max and Feret Breadth ratio. The parameter distribution is close to the normal distribution, which is recommended for use in multiple linear regression analysis.

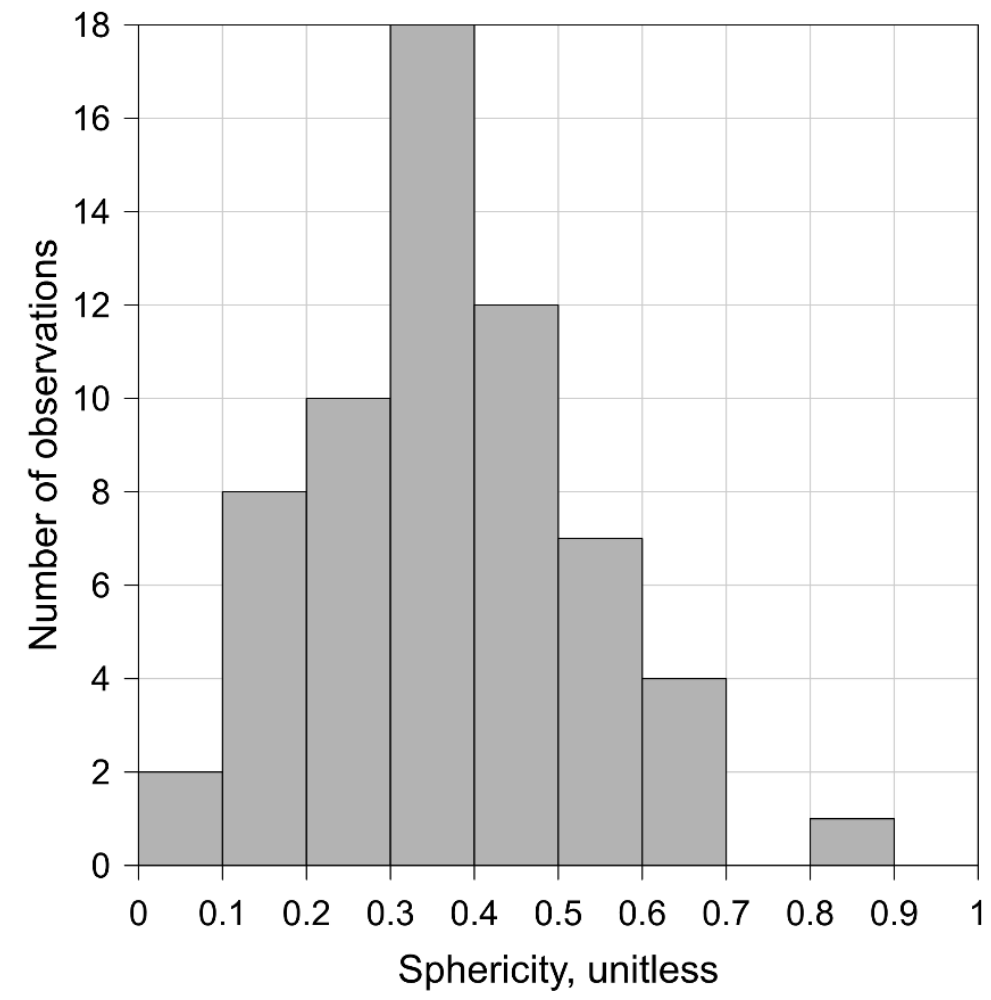

Figure 9. Histogram of object sphericity, based on the largest objects in the samples. 


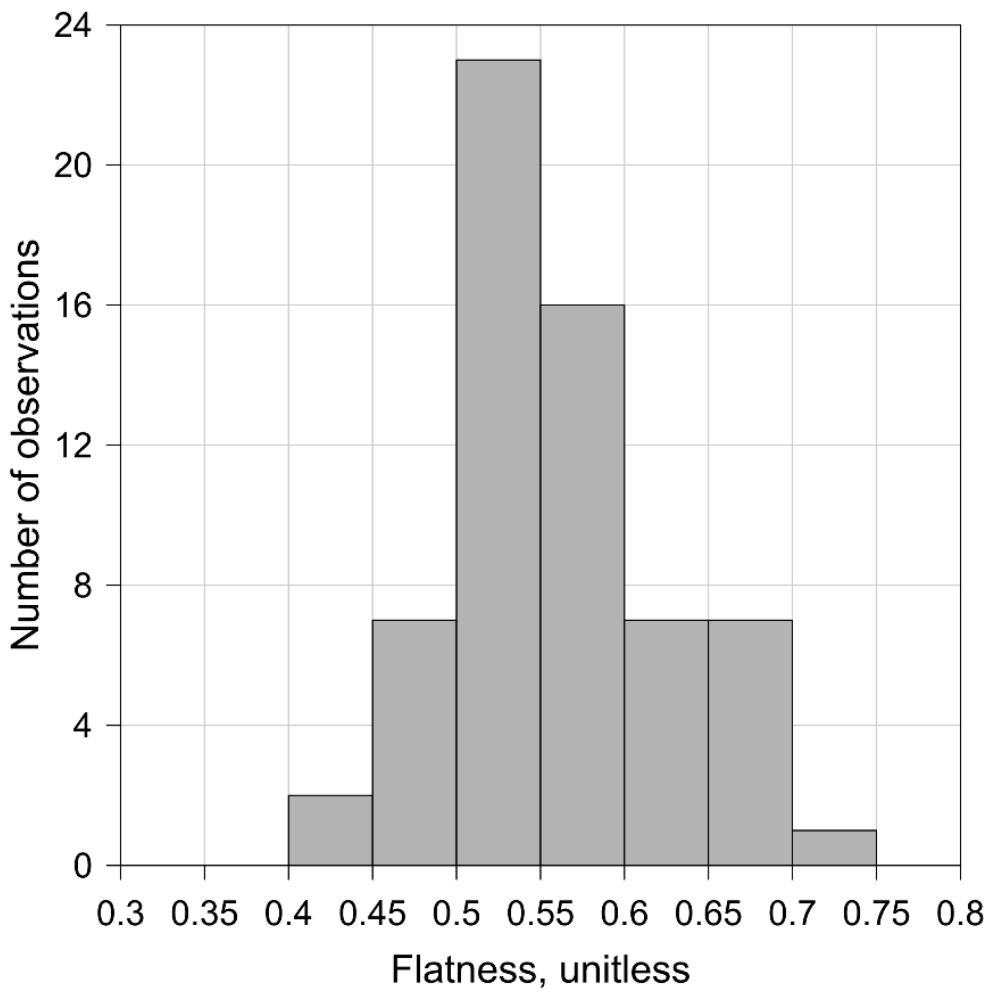

Figure 10. Histogram of object flatness, based on the average values in the samples.

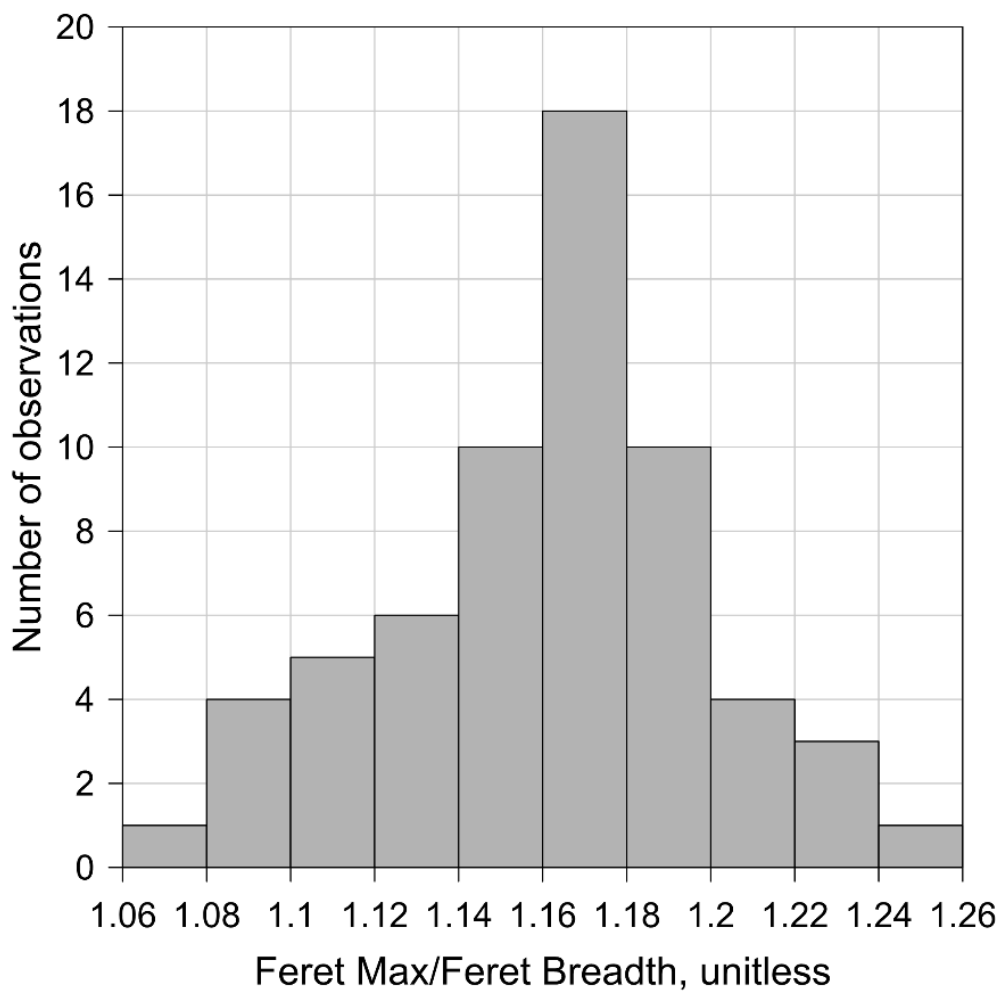

Figure 11. Histogram of Feret Max and Feret Breadth ratio, based on the lower quartile values in the samples.

An exemplary relationship between the logarithm of absolute permeability and the ratio of I 2 and I3 based on the lower quartile data set is shown in Figure 12 for all samples. A decrease in the logarithm of absolute permeability is visible with increasing $\mathrm{I} 2 / \mathrm{I} 3$ ratio. Additionally, an increase of the ratio of Flatness and Anisotropy based on percentile 90 data 
set for all samples results in the increase of the logarithm of absolute permeability. Still, the correlation is moderate (Figure 13).

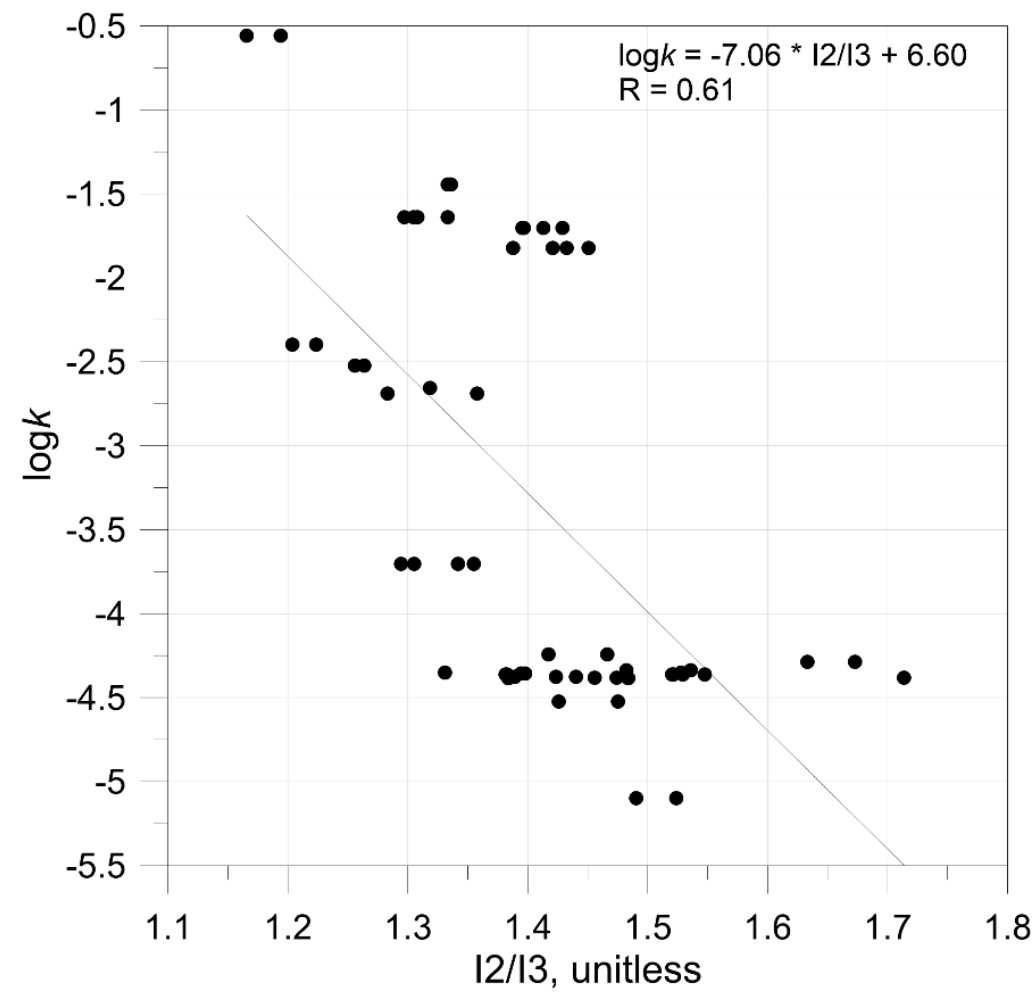

Figure 12. Relationship between the logarithm of absolute permeability and the ratio of I2 and I3 based on lower quartile data set for all samples.

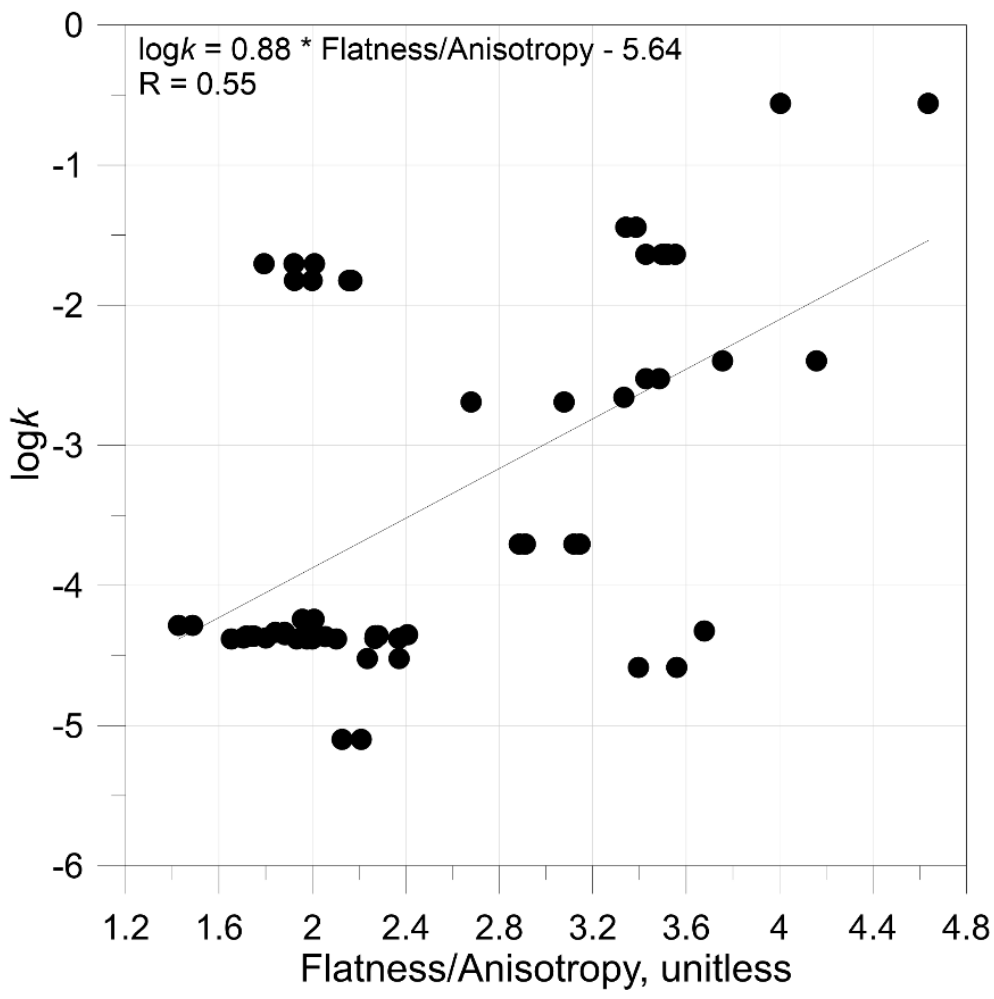

Figure 13. Relationship between the logarithm of absolute permeability and the ratio of Flatness and Anisotropy based on percentile 90 data set for all samples. 
In summary, 49 parameters were used to build the linear relationship with the logarithm of absolute permeability (Table 2).

\subsection{Multiple Linear Regression Analysis}

Multiple linear regression analysis is performed using six independent variables according to recommendations regarding the total number of samples (in this case values of CT parameters): one dependent variable (the logarithm of absolute permeability) and 8-10 independent variables (the parameter values from CT for each sample) [71]. The more independent variables in the analysis, the better the result that can be obtained for dependent variable estimation (logarithm of absolute permeability) using multiple linear regression. Thus, only 6 independent variables are used for the 62 samples. All analyses were performed in Statistica 12 (StatSoft, Krakow, Poland).

First, only basic CT parameters from Table 2 were considered. The correlation coefficient was not high, below 0.55 for most of the basic parameters. Table 3 presents the results for the data sets in which the correlation coefficient was higher than 0.6. The standardized partial regression coefficients inform about the effect of a given parameter on the dependent variable. Mostly, parameters connected with the pore shape have a strong effect on the absolute permeability estimation using MLR.

Table 3. Results of multiple linear regression on standard geometrical parameters from CT images based on different statistical data sets. Symbols: R MLR—correlation coefficient of multiple linear regression.

\begin{tabular}{|c|c|c|}
\hline Type of Data Set & Basic Parameters and Standardized Partial Regression Coefficients & R MLR \\
\hline Lower quartile & $\begin{array}{l}\text { Equivalent Diameter, }-2.0 \text {; Thickness Mean, 1.99; Anisotropy, -1.5; Elongation, }-1.9 \text {; Thickness } \\
\text { StD, 0.34; ShapeVA3D, }-0.44\end{array}$ & 0.76 \\
\hline Upper quartile & $\begin{array}{l}\text { Flatness, 0.73; Feret Min, -2.0; Feret Max, 2.23; Feret Shape, -0.70; Elongation, }-0.43 \text {; ShapeVA3D, } \\
0.28\end{array}$ & 0.67 \\
\hline Percentile 10th & $\begin{array}{l}\text { Thickness Mean, 0.47; Anisotropy, }-0.83 \text {; Elongation, }-1.20 \text {; Flatness, }-0.03 \text {; Feret Min, } 0.48 \text {; Feret } \\
\text { Max, }-0.71\end{array}$ & 0.76 \\
\hline Percentile 90th & Thickness StD, -2.1; Feret Max, -2.6; Feret Breadth, 3.89; Feret Shape, 0.65; I3, 0.18, Sphericity, 0.32 & 0.66 \\
\hline Median & Equivalent Diameter, -1.2; Thickness Mean, 1.44; Flatness, 1.69; I1, -4.4; I2, 4.32; Anisotropy, 1.89 & 0.61 \\
\hline
\end{tabular}

After MLR analysis of each data set, the next step was performed using only the CT parameters that showed a visible, strong linear relationship with the logarithm of absolute permeability. Thus, 49 parameters were chosen for multiple linear regression analysis considering 6 independent variables. For this purpose, 13,983,816 equations were tested to find the best formula. The best result comprised of the following parameters: Feret Breadth/Volume (from the largest object data set), Flatness/Anisotropy (from the upper quartile data set), Feret Max/Flatness (from the lower quartile data set), moments of inertia around the middle principal axis I2/moments of inertia around the longest principal axis I3 (from the lower quartile data set), Anisotropy/Flatness (from the percentile 10 data set), and Flatness/Anisotropy (from the percentile 90 data set).

The correlation coefficient of the equation is 0.82 , while the determination coefficient is $\mathrm{R}^{2}=0.67$. Moreover, it appears that pore flatness and anisotropy play an important role in fluid transport (Table 4). The weakest element is connected with the Feret Breadth, scaled by the Volume of the pores. The equation was also separately applied to the given lithologies. The determination coefficient was higher for sandstone $\left(R^{2}=0.92\right)$ and dolostone $\left(R^{2}=0.69\right)$ but lower for limestone $\left(R^{2}=0.50\right)$. The number of mudstone samples was not sufficient to reach statistical conclusions. The final Equation (2) to calculate the absolute permebaility has the form of:

$$
\log k=b_{0}+b_{1} X_{1}-b_{2} X_{2}-b_{3} X_{3}-b_{4} X_{4}+b_{5} X_{5}+b_{6} X_{6}
$$


where: $k$-absolute permeability of the sample, $\mathrm{mD} ; b_{0}, b_{1}, b_{2}, b_{3}, b_{4}, b_{5}, b_{6}$-partial regression coefficients presented in Table $4 ; X_{1}, X_{2}, X_{3}, X_{4}, X_{5}, X_{6}$ - unitless independent variables, defined and developed in the presented permeability calculation procedure.

Table 4. Results of the best multiple linear regression analysis. Symbols: $b^{*}$-standardized partial regression coefficient, $b$ - partial regression coefficient.

\begin{tabular}{lccc}
\hline \multicolumn{1}{c}{ Parameter Description } & Symbol & $\begin{array}{c}\text { Partial Regression } \\
\text { Coefficient } \\
\boldsymbol{b}\left(\boldsymbol{b}_{\mathbf{0}}-\boldsymbol{b}_{\boldsymbol{6}}\right)\end{array}$ & $\begin{array}{c}\text { Standardized Partial } \\
\text { Regression Coefficient } \\
\boldsymbol{b}^{*}\end{array}$ \\
\hline Intercept in the Equation (2) & - & 14.38 & - \\
Feret Breadth/Volume (from the largest object data set) & $X_{1}$ & 467.62 & 0.28 \\
Flatness / Anisotropy (from the upper quartile data set) & $X_{2}$ & -9.01 & -3.73 \\
Feret Max/Flatness (from the lower quartile data set) & $X_{3}$ & -0.10 & -0.40 \\
I2/I3 (from the lower quartile data set) & $X_{4}$ & -15.22 & -1.38 \\
Flatness/Anisotropy (from the 90th percentile data set) & $X_{5}$ & 5.92 & 3.70 \\
Anisotropy/Flatness (from the 10th percentile data set) & $X_{6}$ & 12.75 & 1.21 \\
\hline
\end{tabular}

A more detailed description of the independent variables is presented below:

$$
X_{1}=\frac{F B}{V}
$$

where: $F B$-Feret Breadth of the largest object in the sample; $V$-Volume of the largest object in the sample.

Feret diameter is a caliper diameter, the distance between the two defined parallel planes. Feret Breadth is a Feret diameter in the direction perpendicular to the line defined by the longest Feret diameter of the object. Volume is a sum of all identified voxels (3D pixel) in the largest object (pore space):

$$
X_{2}=\frac{F_{Q 3}}{A_{Q 3}},
$$

where: $F_{Q 3}-$ flatness of the pores from the upper quartile data set; $A_{Q 3}$-anisotropy of the pores from the upper quartile data set.

The Flatness parameter characterizes flatness of the pores. It is calculated based on the values of the tensor of inertia, which is based on the weighted average (moment) of the image pixels:

$$
F=\frac{I_{3}}{I_{1}},
$$

where: $I_{3}$-moment of inertia around the longest main axis, $I_{1}-$ moment of inertia around the shortest main axis.

Anisotropy parameter characterizes the deviation of the pore's shape from the sphere, based on values of the tensor of inertia:

$$
A=\frac{I_{3}}{I_{1}}+1 .
$$

The $X_{3}$ variable has the form:

$$
X_{3}=\frac{F R_{Q 1}}{F_{Q 1}},
$$

where: $F R_{Q 1}$ 一the maximum Feret diameter from the lower quartile data set; $F_{Q 1}$-flatness of the pores from the lower quartile data set.

The maximum value of Feret diameter is the maximum caliper diameter of the pores in the analyzed sample. 
The following independent variables are in the form of:

$$
X_{4}=\frac{I_{2, Q 1}}{I_{3, Q 1}}
$$

where: $I_{2, Q 1}-$ moment of inertia around the medium main axis from the lower quartile data set, $I_{3, Q 1}-$ moment of inertia around the longest main axis from the lower quartile data set;

$$
X_{5}=\frac{F_{P 90}}{A_{P 90}},
$$

where: $F_{P 90}$-flatness of the pores from the 90th percentile data set; $A_{P 90}$-anisotropy of the pores from the 90 th percentile data set;

$$
X_{6}=\frac{A_{P 10}}{F_{P 10}}
$$

where: $A_{P 10}$-anisotropy of the pores from the 10th percentile data set; $F_{P 10}$-flatness of the pores from the 10th percentile data set.

Flatness divided by Anisotropy (from the upper quartile and 90th percentile data sets) and the moments of inertia around the middle principal axis $\mathrm{I}_{2}$ divided by the moments of inertia around the longest principal axis $\mathrm{I}_{3}$ more greatly affect absolute permeability.

Figure 14 includes a comparison of the logarithm of absolute permeability from the multiple linear regression and the pulse or pressure decay laboratory method. The MLR analysis delivers a formula for absolute permeability, which slightly decreased the estimated permeability compared to the laboratory experiments. The presented formula can be used as a fast method to estimate absolute permeability.

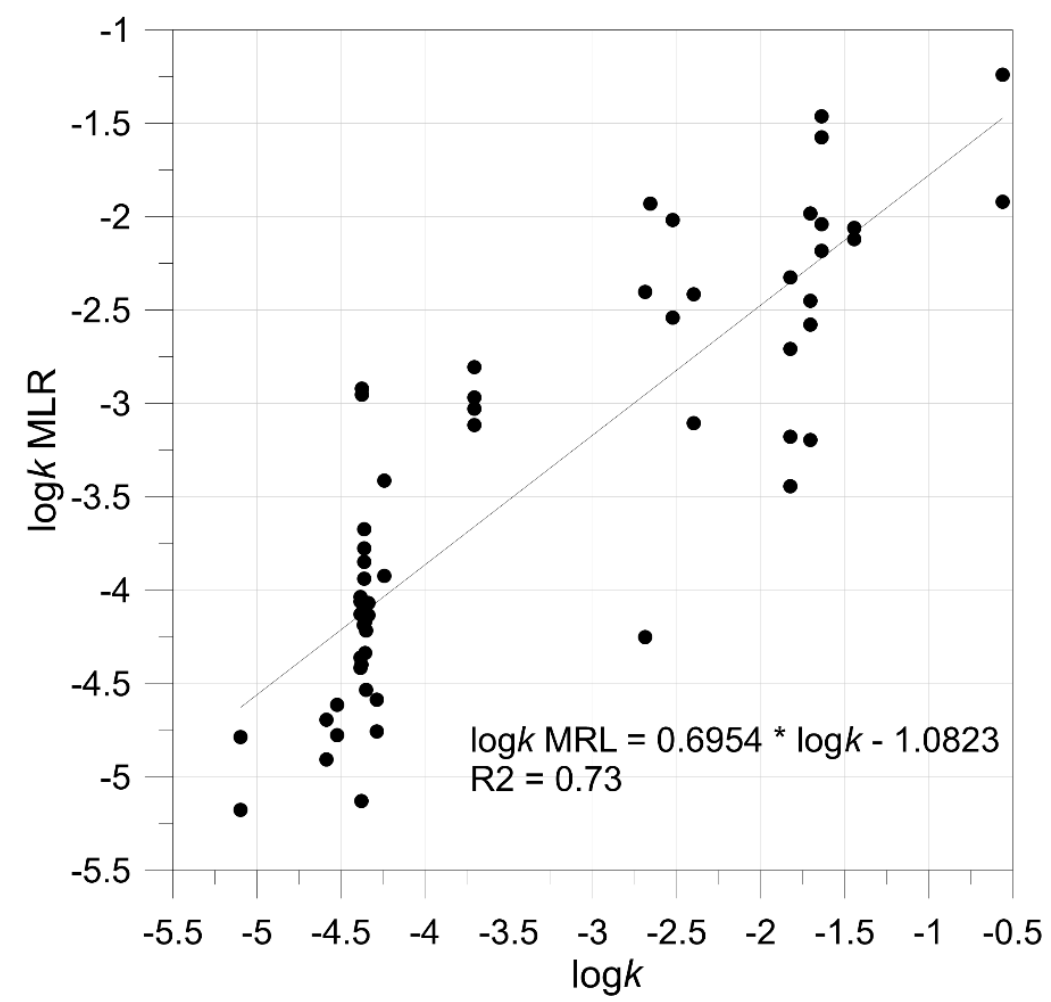

Figure 14. The logarithm of absolute permeability from the multiple linear regression in the function of the logarithm of absolute permeability from pulse or pressure decay laboratory method.

In the formula presented in this paper (Equation (2)), the limitation regards several issues. First of all, it is developed for the unconventional Paleozoic reservoirs, hence it can be applied only for this specific type of rock. Secondly, a part of the information about 
the microporosity can be missed because of the $\mathrm{CT}$ ranges in resolution. The mean square error (MSE) and root mean square error (RMSE) for the developed formula are 0.45 and $0.67 \log \mathrm{mD}$, respectively. The investigation presented in this paper led to the conclusion that CT method gives as a result of interpretation in the form of the geometrical parameters of pores, so the presented permeability formula is directly connected with the pore size influence. Moreover, the application of the different rock types in determining the formula can provide the generalization of the permeability estimation.

Comparing the presented equation (Equation (2)) to the related works from other researchers, it is worth mentioning that this proposition is quicker to use but requires time-consuming CT scanning. Mahdaviara et al. [73] modeled permeability as a function of irreducible water saturation, pore specific surface, and porosity in carbonates using Gaussian Process Regression (state-of-the-art machine learning algorithm). Predicted and real permeability values were similar, but some uncertainties were observed when permeability was lower than $60 \mathrm{mD}$. The mean magnitude relative error (MMRE) and adjusted R-squared for this method were $38 \%$ and 0.98 , respectively. Rios et al. [74] analyzed permeability in sandstones using partial last squares regression technique estimated based on nuclear magnetic resonance data. Their obtained model suggests that this approach is better than models evaluated only on average pore sizes. The RMSE for the presented models were equal to 0.47 and $0.50 \log \mathrm{mD}$. Garcia et al. [75] investigated the effects of particle shape and polydispersity on permeability based on numerical studies. It appeared that grain shape and size distribution have only small effects on the permeability in the studied samples.

\section{Conclusions}

Absolute permeability is essential in determining the reservoir potential. Thus in this paper, six parameters calculated from CT images were considered to present a new formula for absolute permeability. First, 11 data sets were built to contain the basic statistics of 291 parameters from 62 core samples. Each data set contains one statistical parameter calculated for CT parameters based on all identified objects (pores) in the core samples. Multiple linear regression (MLR) provided a solution in the form of an equation with 6 variables after checking approximately 1 million equations. The final version of the formula contains the following parameters: Feret Breadth/Volume (from the largest object data set), Flatness/Anisotropy (from the upper quartile data set), Feret Max/Flatness (from the lower quartile data set), moments of inertia around the middle principal axis I2/moments of inertia around the longest principal axis I3 (from the lower quartile data set), Anisotropy/Flatness (from the 10th percentile data set) and Flatness/Anisotropy (from the 90th percentile data set).

The utility of this formula is connected to two factors: lithology since the geological material consists of sandstones, mudstones, limestones, and dolostones, and application of the geometrical parameters of the pore space from computed X-ray tomography. The analysis is based on the laboratory measurement results of the pulse and pressure decay permeability. The presented formula can be easily applied to estimate absolute permeability before sending core samples for expensive laboratory investigations. Currently, computed X-ray tomography in the form of nano- and microtomography is widely used in the petroleum industry because of its advantages in $2 \mathrm{D}$ and $3 \mathrm{D}$ pore space recognition. CT has an undeniable advantage over other laboratory measurements because it is nondestructive. It is extremely important now when the core data are limited to a minimum. Hence, the presented formula provides insight into the possible permeability values for different materials, which consist of Paleozoic, low-porosity, and low-permeability rocks. The presented formula can play a role in categorizing the material for further laboratory measurements, especially invasive ones (e.g., mercury porosimetry, pulse or pressure decay permeability measurements); can provide a fast interpretation (quick estimation of permeability), and can be used to perform log analysis or well testing. The presented formula also uses a combination of different parameters (also quotient) from CT, which 
presents a new approach. None of the parameters used in the formula are standard parameters but can be easily calculated from CT images. The formula is applicable for tight, low-porous, and low-permeable Paleozoic rocks.

Author Contributions: Conceptualization, P.K.-M. and E.P.; methodology, P.K.-M.; software, P.K.-M., E.P., M.H., P.M., M.J.; validation, P.K.-M., E.P.; formal analysis, P.K.-M.; writing-original draft preparation, P.K.-M., E.P., M.H., P.M., M.D.; writing-review and editing, P.K.-M., E.P., M.H., P.M., M.D.; visualization, P.K.-M.; project administration, P.K.-M.; funding acquisition, P.K.-M. All authors have read and agreed to the published version of the manuscript.

Funding: The research was funded by the National Centre for Research and Development in Poland, program LIDER VI, project no. LIDER/319/L-6/14/NCBR/2015: Innovative method of unconventional oil and gas reservoirs interpretation using computed X-ray tomography.

Institutional Review Board Statement: Not applicable.

Informed Consent Statement: Not applicable.

Data Availability Statement: Restrictions apply to the availability of these data. Data is collected at AGH University of Science and Technology, Krakow, Poland.

Acknowledgments: The CT analyses were performed in Laboratory of Micro and Nano Tomography, Faculty of Physics and Applied Computer Science, AGH University of Science and Technology in Krakow, Poland. The authors thank Polish Oil \& Gas Company and Orlen Upstream Co. for all the materials. Statistica software (StatSoft Poland) is available at AGH University of Science and Technology in Kraków (Poland).

Conflicts of Interest: The authors declare no conflict of interest. 


\section{Appendix A}

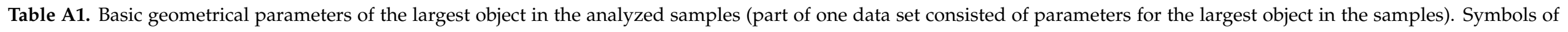

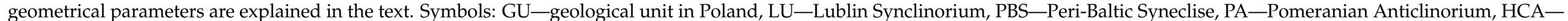

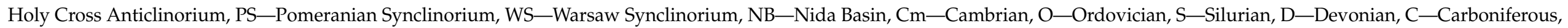

$\mathrm{P}$-Permian, ss—sandstone, mds—mudstone, lms—limestone, dls—dolostone.

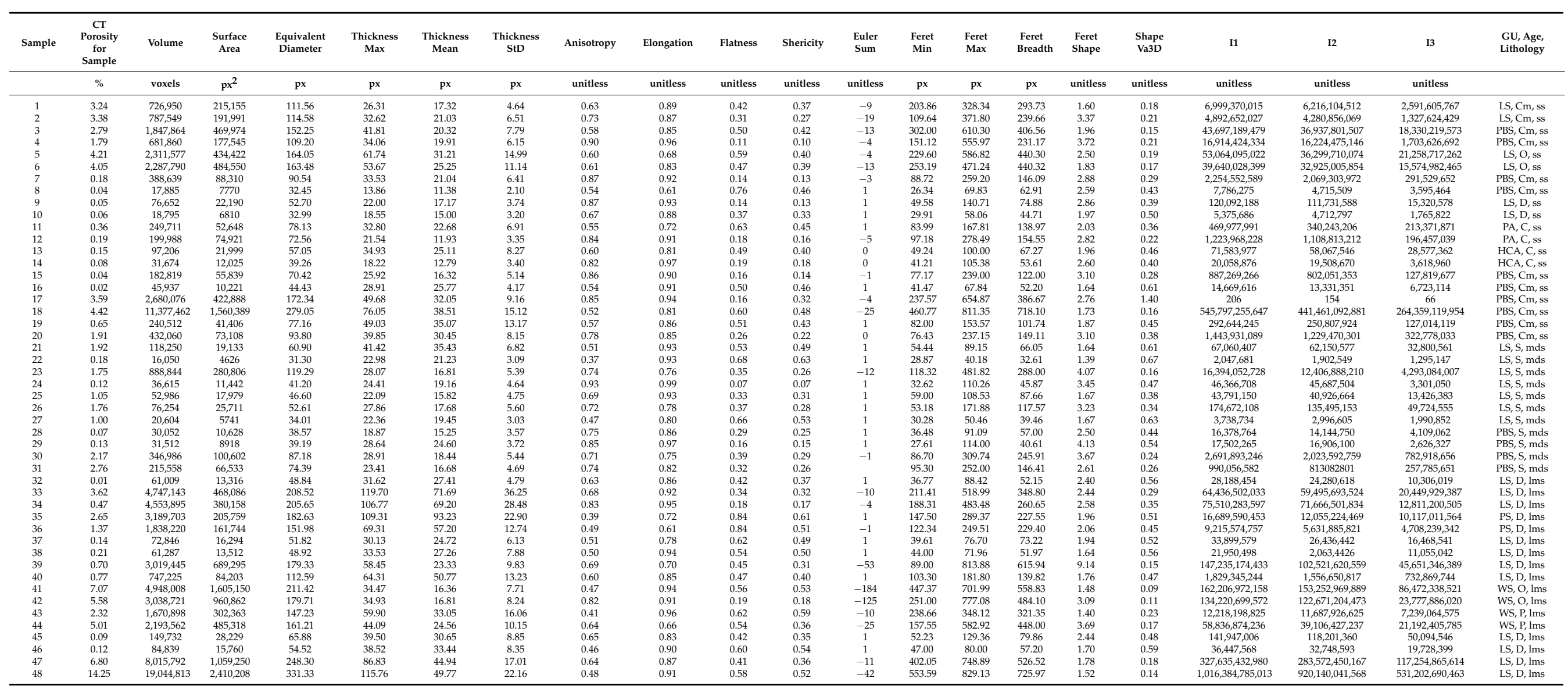


Table A1. Cont.

\begin{tabular}{|c|c|c|c|c|c|c|c|c|c|c|c|c|c|c|c|c|c|c|c|c|c|}
\hline Sample & $\begin{array}{c}\mathrm{CT} \\
\text { Porosity } \\
\text { for } \\
\text { Sample } \\
\end{array}$ & Volume & $\begin{array}{c}\text { Surface } \\
\text { Area }\end{array}$ & $\begin{array}{l}\text { Equivalent } \\
\text { Diameter }\end{array}$ & $\begin{array}{l}\text { Thickness } \\
\text { Max }\end{array}$ & $\begin{array}{l}\text { Thickness } \\
\text { Mean }\end{array}$ & $\begin{array}{c}\text { Thickness } \\
\text { StD }\end{array}$ & Anisotropy & Elongation & Flatness & Shericity & $\begin{array}{l}\text { Euler } \\
\text { Sum }\end{array}$ & $\begin{array}{l}\text { Feret } \\
\text { Min }\end{array}$ & $\begin{array}{l}\text { Feret } \\
\text { Max }\end{array}$ & $\begin{array}{c}\text { Feret } \\
\text { Breadth }\end{array}$ & $\begin{array}{l}\text { Feret } \\
\text { Shape }\end{array}$ & $\begin{array}{l}\text { Shape } \\
\text { Va3D }\end{array}$ & I1 & I2 & I3 & $\begin{array}{l}\text { GU, Age, } \\
\text { Lithology }\end{array}$ \\
\hline & $\%$ & voxels & $\mathrm{px}^{2}$ & $\mathrm{px}$ & $\mathrm{px}$ & $\mathrm{px}$ & $\mathrm{px}$ & unitless & unitless & unitless & unitless & unitless & $\mathrm{px}$ & $\mathrm{px}$ & $\mathrm{px}$ & unitless & unitless & unitless & unitless & unitless & \\
\hline 49 & 0.44 & $1,210,362$ & 139,086 & 132.22 & 77.82 & 53.32 & 21.03 & 0.49 & 0.73 & 0.69 & 0.51 & -1 & 127.37 & 242.95 & 200.15 & 1.89 & 0.39 & $4,384,387,635$ & $3,216,307,385$ & $2,224,065,872$ & $\mathrm{NB}, \mathrm{D}, \mathrm{dls}$ \\
\hline $\begin{array}{l}50 \\
51\end{array}$ & $\begin{array}{l}0.77 \\
0.19\end{array}$ & $\begin{array}{l}1,020,579 \\
2110,189\end{array}$ & $\begin{array}{l}124,872 \\
47553\end{array}$ & $\begin{array}{l}{ }_{724.92} \\
73.77\end{array}$ & $\begin{array}{l}74.00 \\
28.64\end{array}$ & $\begin{array}{l}51.34 \\
22.01\end{array}$ & $\begin{array}{l}21.91 \\
5.71\end{array}$ & $\begin{array}{l}0.39 \\
0.71\end{array}$ & $\begin{array}{l}0.70 \\
0.78\end{array}$ & $\begin{array}{l}0.86 \\
0.38\end{array}$ & $\begin{array}{l}0.61 \\
0.29\end{array}$ & 1 & $\begin{array}{l}109.59 \\
68.00\end{array}$ & $\begin{array}{l}210.45 \\
178.23\end{array}$ & $\begin{array}{l}188.38 \\
120.86\end{array}$ & $\begin{array}{l}1.91 \\
2.62\end{array}$ & $\begin{array}{l}0.39 \\
0.36\end{array}$ & 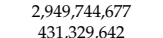 & $\begin{array}{r}2,079,0002,498 \\
3355771,29\end{array}$ & $\begin{array}{r}1,792,628,271 \\
126,756088\end{array}$ & $\begin{array}{l}\text { NB, D, dls } \\
\text { PL, d, dls }\end{array}$ \\
\hline $\begin{array}{l}51 \\
52\end{array}$ & $\begin{array}{l}0.19 \\
0.08\end{array}$ & $\begin{array}{l}210,1989 \\
24,267\end{array}$ & $\begin{array}{l}47,553 \\
8050\end{array}$ & $\begin{array}{l}73.77 \\
35.92\end{array}$ & $\begin{array}{l}28.64 \\
21.26\end{array}$ & $\begin{array}{l}22.01 \\
16.25\end{array}$ & $\begin{array}{l}5.71 \\
5.23\end{array}$ & $\begin{array}{l}0.71 \\
0.67\end{array}$ & $\begin{array}{l}0.78 \\
0.90\end{array}$ & $\begin{array}{l}0.38 \\
0.37\end{array}$ & $\begin{array}{l}0.29 \\
0.33\end{array}$ & 1 & $\begin{array}{l}68.00 \\
29.48\end{array}$ & $\begin{array}{l}178.23 \\
66.03\end{array}$ & $\begin{array}{l}120.86 \\
53.69\end{array}$ & $\begin{array}{l}2.62 \\
2.17\end{array}$ & $\begin{array}{l}0.36 \\
0.50\end{array}$ & $\begin{array}{r}351,2,39,6424 \\
7,069,643\end{array}$ & $\begin{array}{c}353,7,7,619 \\
6,359,418\end{array}$ & $\begin{array}{r}21,0,330,008 \\
2,37,192\end{array}$ & $\begin{array}{l}\text { PL, I, dls } \\
\text { PL P dls }\end{array}$ \\
\hline 53 & 0.34 & $\begin{array}{l}24,26 \% \\
344,255\end{array}$ & 71,491 & $\begin{array}{l}83.92 \\
86.95\end{array}$ & $\begin{array}{l}11.26 \\
33.17\end{array}$ & $\begin{array}{l}10.29 \\
24.63\end{array}$ & $\begin{array}{l}3.28 \\
6.89\end{array}$ & 0.76 & 0.83 & 0.29 & 0.24 & -1 & $\begin{array}{l}29.40 \\
82.00\end{array}$ & $\begin{array}{l}\text { Oo.0. } \\
244.33\end{array}$ & $\begin{array}{l}5.3099 \\
149.89\end{array}$ & 2.98 & 0.33 & $\begin{array}{l}1,009,049 \\
1,079,288,906\end{array}$ & $\begin{array}{l}0,030,9110 \\
890,942,737\end{array}$ & $\begin{array}{r}2,35,81,192 \\
255,812,404\end{array}$ & PL, P, dls \\
\hline 54 & 0.14 & 36,932 & 10,216 & 41.32 & 23.15 & 19.64 & 4.21 & 0.64 & 0.89 & 0.41 & 0.36 & 1 & 41.65 & 72.87 & 53.86 & 1.68 & 0.52 & $13,824,225$ & $12,304,972$ & $5,003,150$ & $\mathrm{PL}, \mathrm{P}$, dls \\
\hline 55 & 0.48 & $\begin{array}{l}60,398 \\
2500 \%\end{array}$ & 13,574 & 48.68 & 33.17 & 27.51 & 7.87 & 0.53 & 0.85 & 0.55 & 0.47 & 1 & 46.60 & 87.57 & 66.01 & 1.89 & 0.55 & $27,674,773$ & $23,507,168$ & $12,986,944$ & PL, P, dls \\
\hline $\begin{array}{l}56 \\
57\end{array}$ & $\begin{array}{l}0.53 \\
0.59\end{array}$ & $\begin{array}{l}{ }^{25} 5,006 \\
42,233\end{array}$ & $\begin{array}{l}9600 \\
16952\end{array}$ & $\begin{array}{l}36.28 \\
43.21\end{array}$ & $\begin{array}{l}22.89 \\
23.07\end{array}$ & $\begin{array}{l}15.18 \\
1782\end{array}$ & $\begin{array}{l}6.13 \\
5.37\end{array}$ & $\begin{array}{l}0.62 \\
0.73\end{array}$ & $\begin{array}{l}0.73 \\
0.82\end{array}$ & 0.52 & 0.38 & 3 & 30.44 & $\begin{array}{l}75.83 \\
9362\end{array}$ & $\begin{array}{r}69.49 \\
6857\end{array}$ & $\begin{array}{r}2.49 \\
2,23\end{array}$ & 0.43 & $\begin{array}{l}12,744,742 \\
33518,57\end{array}$ & $\begin{array}{r}9,288,854 \\
7 \\
75757637\end{array}$ & $\begin{array}{l}4,784,693 \\
8936365\end{array}$ & PL, P, dls \\
\hline $\begin{array}{l}57 \\
58\end{array}$ & $\begin{array}{l}0.59 \\
0.42\end{array}$ & $\begin{array}{l}42,233 \\
38,205\end{array}$ & $\begin{array}{l}13,592 \\
8674\end{array}$ & $\begin{array}{l}43.21 \\
41.79\end{array}$ & $\begin{array}{l}23.07 \\
28.50\end{array}$ & $\begin{array}{l}17.82 \\
25.30\end{array}$ & $\begin{array}{l}5.37 \\
4.35\end{array}$ & $\begin{array}{l}0.73 \\
0.37\end{array}$ & $\begin{array}{l}0.82 \\
0.75\end{array}$ & $\begin{array}{l}0.32 \\
0.84\end{array}$ & 0.27 & $\begin{array}{l}1 \\
4\end{array}$ & $\begin{array}{l}41.60 \\
33.41\end{array}$ & $\begin{array}{l}93.62 \\
59.03\end{array}$ & $\begin{array}{l}68.51 \\
5489\end{array}$ & $\begin{array}{l}2.23 \\
176\end{array}$ & 0.42 & $\begin{array}{l}33,518,577 \\
9666617\end{array}$ & $\begin{array}{l}27,576,3727 \\
720243\end{array}$ & $\begin{array}{l}8,936,365 \\
6,060,075\end{array}$ & 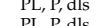 \\
\hline 60 & 1.09 & 914,202 & $\begin{array}{l}189,000 \\
\end{array}$ & 120.42 & 47.71 & 25.33 & 10.19 & 0.59 & 0.82 & 0.50 & 0.41 & -2 & 164.58 & 280.66 & 271.42 & 1.62 & 0.24 & $6,255,616,630$ & $5,132,522,959$ & $2,578,927,813$ & $\mathrm{PL}, \mathrm{P}, \mathrm{dls}$ \\
\hline 61 & 13.49 & $\begin{array}{l}57,296,349 \\
70250\end{array}$ & $\begin{array}{l}5,659,587 \\
8,97707\end{array}$ & $\begin{array}{l}478.31 \\
53330\end{array}$ & 173.18 & 80.07 & 53.43 & 0.15 & 0.88 & 0.96 & 0.85 & -452 & 700.00 & 1099.77 & 958.62 & 1.56 & 0.13 & $3,237,473,841,968$ & $2,843,222,125,829$ & $2,739,463,376,253$ & $\begin{array}{l}\text { PL, P, dls } \\
P, \mathrm{~d}\end{array}$ \\
\hline 62 & 10.33 & $79,295,729$ & $8,877,597$ & 533.03 & 170.47 & 64.95 & 43.31 & 0.54 & 0.89 & 0.52 & 0.46 & -466 & 700.00 & 1622.12 & 1002.13 & 2.29 & 0.10 & $11,871,921,780,168$ & $10,568,080,341,865$ & $5,490,014,287,950$ & PL, P, dls \\
\hline
\end{tabular}


Table A2. List of parameters.

\begin{tabular}{|c|c|}
\hline Name, Symbol & Description \\
\hline Volume, $V$ & Total number of voxels \\
\hline Surface Area & The surface area of the object expressed in voxels that are directly adjacent to the object's surroundings \\
\hline Equivalent Diameter & Diameter of the sphere with a volume equal to the volume of the object \\
\hline $\mathrm{II}, \mathrm{I} 2, \mathrm{I}, \mathrm{I}_{1}, \mathrm{I}_{2}, \mathrm{I}_{3}$ & Moment of inertia around the shortest, medium and the longest main axis, based on the weighted average (moment) of the image pixels \\
\hline Thickness Max & Maximum thickness in the object, indirectly maximum diameter of the object \\
\hline Thickness Min & Minimum thickness in the object \\
\hline Thickness Mean & Mean thickness in the object, indirectly mean diameter of the object \\
\hline Thickness Std & Standard deviation of the thickness in the object \\
\hline Anisotropy, $A$ & Parameter determining the deviation of the object's shape from the sphere, based on tensor of inertia; Anisotropy $=(13 / \mathrm{I} 1)+1$, pore shape anisotropy \\
\hline Elongation & Elongation of the object, based on tensor of inertia; Elongation $=(\mathrm{I} 2 / \mathrm{I} 1)$ \\
\hline Flatness, $F$ & Flatness of the object, based on tensor of inertia; Flatness $=(\mathrm{I} 3 / \mathrm{I} 1)$ \\
\hline Sphericity & Sphericity of the object, based on volume and surface area; Sphericity $=\left(\pi^{(1 / 3)} *(6 * \text { Volume })^{(2 / 3)}\right) /$ Surface Area \\
\hline Euler Sum & Euler characteristic \\
\hline Feret Diameter & Caliper diameter, the distance between the two defined parallel planes \\
\hline Feret Min & Minimum value of Feret diameter \\
\hline Feret Max, $F R$ & Maximum value of Feret diameter, so maximum caliper diameter \\
\hline Feret Breadth, $F B$ & Maximum Feret diameter in the direction perpendicular to the line defined by the longest Feret diameter of the object \\
\hline Feret Shape & The ratio of the maximum length of the Feret diameter measured in the direction perpendicular to the line defined by the shortest Feret diameter to the length of the shortest Feret diameter \\
\hline ShapeVa3D & Shape factor, calculated based on the surface area of the object and the cross-sectional area of the object's shape; shapeva $3 \mathrm{~d}=\left(\right.$ Surface Area $\left.{ }^{3}\right) /\left(36^{*} \pi 0^{*}{ }^{*}\right.$ Volume $\left.^{2}\right)$ \\
\hline
\end{tabular}

\section{References}

1. Chen, X.; Yao, G. An improved model for permeability estimation in low permeable porous media based on fractal geometry and modified Hagen-Poiseuille flow. Fuel 2017, 10, 748-757. [CrossRef]

2. Germanou, L.; Ho, M.T.; Zhang, Y.; Wu, L. Intrinsic and apparent gas permeability of heterogeneous and anisotropic ultra-tight porous media. J. Nat. Gas Sci. Eng. 2018, 60, 271-283. [CrossRef]

3. Alfi, M.; Hosseini, S.A.; Enriquez, D.; Zhang, T. A new technique for permeability calculation of core samples from unconventional gas reservoirs. Fuel 2019, 235, 301-305. [CrossRef]

4. Farmani, Z.; Azin, R.; Mohamadi-Baghmolaei, M.; Fatehi, R.; Escrochi, M. Experimental and theoretical study of gas/oil relative permeability. Comput. Geosci. 2019, 23, 567-581. [CrossRef]

5. Kozeny, J. Uber kapillare Leitung des Wassers im Boden. Sitzungsber Akad. Wiss, Wien. Math Naturwiss 1927, 136/2a, 271-306.

6. Ciu, J.; Cheng, L.; Li, L. Apparent permeability and representative size of shale: A numerical study on the effects of organic matter. Comput. Geosci. 2018, 22, 1083-1091.

7. Rezaee, R.; Saeedi, A.; Clennell, B. Tight gas sands permeability estimation from mercury injection capillary pressure and nuclear magnetic resonance data. J. Pet. Sci. Eng. 2012, 88-89, 92-99. [CrossRef]

8. Zheng, J.; Wang, Z.; Gong, W.; Ju, Y.; Wang, M. Characterization of nanopore morphology of shale and its effects on gas permeability. J. Nat. Gas Sci. Eng. 2017, 47, 83-90. [CrossRef]

9. Ghanizadeh, A.; Clarkson, C.R.; Aquino, S.; Vahedian, A. Permeability standards for tight rocks: Design, manufacture and validation. Fuel 2017, 197, 121-137. [CrossRef]

10. Ghanbarian, B.; Torres-Verdin, C.; Lake, L.W.; Marder, M. Gas permeability in unconventional tight sandstones: Scaling up from pore to core. J. Pet. Sci. Eng. 2019, 173, 1163-1172. [CrossRef]

11. Davarpanah, A.; Mirshekari, B.; Behbahani, T.J.; Hemmati, M. Integrated production logging tools approach for convenient experimental individual layer permeability measurements in a multi-layered fractured reservoir. J. Pet. Explor. Prod. Technol. 2018, 8,743-751. [CrossRef]

12. Hu, X.; Xie, J.; Cai, W.; Wang, R.; Davarpanah, A. Thermodynamic effects of cycling carbon dioxide injectivity in shale reservoirs. J. Pet. Sci. Eng. 2020, 195, 107717. [CrossRef]

13. Esfandyari, H.; Hoseini, A.H.; Shadizadeh, S.R.; Davarpanah, A. Simultaneous evaluation of capillary pressure and wettability alteration based on the USBM and imbibition tests on carbonate minerals. J. Pet. Sci. Eng. 2021, 200, 108285. [CrossRef]

14. Davarpanah, A. Parametric Study of Polymer-Nanoparticles-Assisted Injectivity Performance for Axisymmetric Two-Phase Flow in EOR Processes. Nanomaterials 2020, 10, 1818. [CrossRef] [PubMed]

15. Hu, X.; Li, M.; Peng, C.; Davarpanah, A. Hybrid Thermal-Chemical Enhanced Oil Recovery Methods: An Experimental Study for Tight Reservoirs. Symmetry 2020, 12, 947. [CrossRef]

16. Davarpanah, A.; Mirshekari, B. Experimental Investigation and Mathematical Modeling of Gas Diffusivity by Carbon Dioxide and Methane Kinetic Adsorption. Ind. Eng. Chem. Res. 2019, 58, 12392-12400. [CrossRef]

17. Davarpanah, A. Feasible analysis of reusing flowback produced water in the operational performances of oil reservoirs. Environ. Sci. Pollut. Res. 2018, 25, 35387-35395. [CrossRef]

18. Davarpanah, A.; Mirshekari, B.; Razmjoo, A. A parametric study to numerically analyze the formation damage effect. Energy Explor. Exploit. 2019, 38, 555-568. [CrossRef]

19. Latief, F.D.E.; Fauzi, U. Kozeny-Carman and empirical formula for the permeability of computer rock models. Int. J. Rock Mech. Min. Sci. 2012, 50, 117-123. [CrossRef]

20. Li, B.; Wong, R.C.K.; Heidari, S. A modified Kozeny-Carman model for estimating anisotropic permeability of soft mudrocks. Mar. Pet. Geol. 2018, 98, 356-368. [CrossRef] 
21. Wang, F.; Jiao, L.; Lian, P.; Zeng, J. Apparent gas permeability, intrinsic permeability and liquid permeability of fractal porous media: Carbonate rock study with experiments and mathematical modeling. J. Pet. Sci. Eng. 2019, 173, 1304-1315. [CrossRef]

22. Gholampour, F.; Mahdiyar, H. A new correlation for relative permeability in gas-condensate reservoirs. J. Pet. Sci. Eng. 2019, 172, 831-838. [CrossRef]

23. Kayser, A.; Knackstedt, M.; Ziauddin, M. A closer look at pore geometry. Oilfield Rev. 2006, 18, 4-13.

24. Karpyn, Z.T.; Alajmi, A.; Radaelli, F.; Halleck, P.M.; Grader, A.S. X-ray CT and hydraulic evidence for a relationship between fracture conductivity and adjacent matrix porosity. Eng. Geol. 2009, 103, 139-145. [CrossRef]

25. Guo, X.; Shen, Y.; He, S. Quantitative pore characterization and the relationship between pore distributions and organic matter in shale based on Nano-CT image analysis: A case study for a lacustrine shale reservoir in the Triassic Chang 7 member, Ordos Basin, China. J. Nat. Gas Eng. 2015, 27, 1630-1640. [CrossRef]

26. Gong, L.; Nie, L.; Xu, Y. Geometrical and Topological Analysis of Pore Space in Sandstones Based on X-ray Computed Tomography. Energies 2020, 13, 3774. [CrossRef]

27. Kaczmarek, Ł.; Kozłowska, A.; Maksimczuk, M.; Wejrzanowski, T. The use of X-ray computed microtomography for graptolite detection in rock based on core internal structure visualization. Acta Geol. Pol. 2017, 67, 299-306. [CrossRef]

28. Shiqi, L.; Sang, S.; Wang, G.; Ma, J.; Wang, X.; Wang, W.; Du, Y.; Wang, T. FIB-SEM and X-ray CT characterization of interconnected pores in high-rank coal formed from regional metamorphism. J. Pet. Sci. Eng. 2017, 148, $21-31$.

29. Degruyter, W.; Burgisser, A.; Bachmann, O.; Malaspinas, O. Synchrotron X-ray microtomography and lattice Boltzmann simulations of gas flow through volcanic pumices. Geosphere 2010, 6, 470-481. [CrossRef]

30. Wang, J.; Zhao, J.; Zhang, Y.; Wang, D.; Li, Y.; Song, Y. Analysis of the effect of particle size on permeability in hydrate-bearing porous media using pore network models combined with CT. Fuel 2016, 163, 34-40. [CrossRef]

31. Trykozko, A.; Peszynska, M.; Dohnalik, M. Modeling non-Darcy flows in realistic pore-scale proppant geometries. Comput. Geotech. 2016, 71, 352-360. [CrossRef]

32. Lu, X.; Armstrong, R.T.; Mostaghimi, P. High-pressure X-ray imaging to interpret coal permeability. Fuel 2018, 226 , 573-582. [CrossRef]

33. Madejski, P.; Krakowska, P.; Habrat, M.; Puskarczyk, E.; Jędrychowski, M. Comprehensive approach for porous materials analysis using a dedicated preprocessing tool for mass and heat transfer modeling. J. Therm. Sci. 2018, 27, 479-486. [CrossRef]

34. Ziółkowski, P.; Badur, J. On Navier slip and Reynolds transpiration numbers. Archiv. Mech. 2018, 70, $269-300$.

35. Kayabasi, A.; Yesiloglu-Gultekin, N.; Gokceoglu, C. Use of non-linear prediction tools to assess rock mass permeability using various discontinuity parameters. Eng. Geol. 2015, 185, 1-9. [CrossRef]

36. Habibi, M.J.; Reza Mokhtari, A.; Baghbanan, A.; Namdari, S. Prediction of permeability in dual fracture media by multivariate regression analysis. J. Pet. Sci. Eng. 2014, 120, 194-201. [CrossRef]

37. Puskarczyk, E.; Jarzyna, J.; Porębski, S. Application of multivariate statistical methods for characterizing heterolithic reservoirs based on wireline logs_Example from the Carpathian Foredeep Basin (Middle Miocene, SE Poland). Geol. Q. 2015, 59, 167-168

38. Zhang, Z.; Li, P.; Yuan, Y.; Liu, K.; Hao, J.; Zou, H. Quantitative Prediction of Fractures in Shale Using the Lithology Combination Index. Minerals 2020, 10, 569. [CrossRef]

39. Zhang, G.; Wang, Z.; Li, H.; Sun, Y.; Zhang, Q.; Chen, W. Permeability prediction of isolated channel sands using machine learning. J. Appl. Geophys. 2018, 159, 605-615. [CrossRef]

40. Sudakov, O.; Burnaev, E.; Koroteev, D. Driving digital rock towards machine learning: Predicting permeability with gradient boosting and deep neural networks. Comput. Geosci. 2019, 127, 91-98. [CrossRef]

41. Erofeev, A.; Orlov, D.; Ryzhov, A.; Koroteev, D. Prediction of Porosity and Permeability Alteration Based on Machine Learning Algorithms. Transp. Porous Media 2019, 128, 677-700. [CrossRef]

42. Roshani, G.H.; Hanus, R.; Khazaei, A.; Zych, M.; Nazemi, E.; Mosorov, V. Density and velocity determination for single-phase flow based on radiotracer technique and neural networks. Flow Meas. Instrum. 2018, 61, 9-14. [CrossRef]

43. Wu, J.; Yin, X.; Xiao, H. Seeing permeability from images: Fast prediction with convolutional neural networks. Sci. Bull. 2018, 63, 1215-1222. [CrossRef]

44. Wendt, W.A.; Sakurai, S.; Nelson, P.H. Permeability Prediction from Well logs using Multiple Regression. In Reservoir Characterization, 1st ed.; Lake, L.W., Carroll, H.B., Eds.; Elsevier Academic Press: Cambridge, MA, USA, 1986; pp. 181-221.

45. Marsal, D. Statistic for Geoscientists, 1st ed.; Pergamon: Oxford, UK, 1987; pp. 89-114.

46. Civan, F. Effective Correlation of Apparent Gas Permeability in Tight Porous Media. Transp. Porous Media 2010, 82, 375-384. [CrossRef]

47. Javadpour, F. Nanopores and Apparent Permeability of Gas Flow in Mudrocks (Shales and Siltstone). J. Can. Pet. Technol. 2009, $48,16-21$. [CrossRef]

48. Singh, K. How boundary slip controls emergent Darcy flow of liquids in tortuous and in capillary pores. Phys. Rev. E 2020, 102, 013101. [CrossRef] [PubMed]

49. Kelly, S.; El-Sobky, H.; Torres-Verdin, C.; Balhoff, M.T. Assessing the utility of FIB-SEM images for shale digital rock physics. Adv. Water Resour. 2016, 95, 302-316. [CrossRef]

50. Soulaine, C.; Gjetvaj, F.; Garing, C.; Roman, S.; Russian, A.; Gouze, P.; Tchelepi, H.A. The Impact of Sub-Resolution Porosity of X-ray Microtomography Images on the Permeability. Transp. Porous Media 2016, 113, 227-243. [CrossRef] 
51. Backeberg, N.R.; Iacoviello, F.; Rittner, M.; Mitchell, T.M.; Jones, A.P.; Day, R.; Wheeler, J.; Shearing, P.R.; Vermeesch, P.; Striolo, A. Quantifying the anisotropy and tortuosity of permeable pathways in clay-rich mudstones using models based on X-ray tomography. Sci. Rep. 2017, 7, 14838. [CrossRef]

52. Bhandari, A.R.; Flemings, P.B.; Polito, P.J.; Cronin, M.B.; Bryant, S.L. Anisotropy and Stress Dependence of Permeability in the Barnett Shale. Transp. Porous Media 2015, 108, 393-411. [CrossRef]

53. Clerke, A.E.; Mueller, H.W., III; Philips, E.C.; Eyvazzadeh, R.Y.; Jones, D.H.; Ramamoorthy, R.; Srivastava, A. Application of Thomeer Hyperbolas to decode the pore systems, facies and reservoir properties of the Upper Jurassic Arab D Limestone, Gghawar field, Saudi Arabia: A “Rosetta Stone” approach. Gulf PetroLink, Bahrain. GeoArabia 2018, 13, 113-160.

54. Zhang, Y.; Yang, B.; Yang, Z.; Ye, G. Ink-bottle Effect and Pore Size Distribution of Cementitious Materials Identified by Pressurization-Depressurization Cycling Mercury Intrusion Porosimetry. Materials 2019, 12, 1454. [CrossRef]

55. Moro, F.; Bohni, H. Ink-Bottle Effect in Mercury Intrusion Porosimetry of Cement-Based Materials. J. Colloid Int. Sci. 2002, 246, 135-149. [CrossRef]

56. Cnudde, V.; Boone, M. High-resolution X-ray computed tomography in geosciences: A review of the current technology and applications. Earth Sci. Rev. 2013, 123, 1-17. [CrossRef]

57. Ketcham, R.A.; Carlson, W.D. Acquisition, optimization and interpretation of X-ray computed tomographic imagery: Applications to the geosciences. Comput. Geosci. 2001, 27, 381-400. [CrossRef]

58. Stock, S.R. MicroComputed Tomography. Methodology and Application; CRC Press: Boca Raton, FL, USA, 2008 ; pp. 1-336.

59. Wellington, S.L.; Vinegar, H.J. X-ray computerized tomography. J. Pet. Technol. 1987, 39, 885-898. [CrossRef]

60. Josh, M.; Esteban, L.; Delle Piane, C.; Sarout, J.; Dewhurst, D.N.; Clennell, M.B. Laboratory characterization of shale properties. J. Pet. Sci. Eng. 2012, 88-89, 107-124. [CrossRef]

61. Guntoro, P.I.; Ghorbani, Y.; Koch, P.-H.; Rosenkranz, J. X-ray Microcomputed Tomography ( $\mu$ CT) for Mineral Characterization: A Review of Data Analysis Method. Minerals 2019, 9, 183. [CrossRef]

62. Zhang, L.; Lu, S.; Xiao, D.; Li, B. Pore structure characteristics of tight sandstones in the northern Songliao Basin, China. Mar. Pet. Geol. 2017, 88, 170-180. [CrossRef]

63. Mukhametdinova, A.; Kazak, A.; Karamov, T.; Bogdanovich, N.; Serkin, M.; Melekhin, S.; Cheremisin, A. Reservoir Properties of Low-Permeable Carbonate Rocks: Experimental Feature. Energies 2020, 13, 2233. [CrossRef]

64. Feldkamp, L.; Davis, L.; Kress, J. Practical cone-beam algorithm. J. Opt. Soc. Am. A 1984, 1, 612-619. [CrossRef]

65. Jędrychowski, M.; Krakowska, P.; Puskarczyk, E.; Madejski, P.; Habrat, M. Segmentation Method of Pore Space Based on Fourier Transform Processing of Micro-CT 3D Data. In Proceedings of the 79th EAGE Conference and Exhibition 2017, Paris, France, 12-15 June 2017; EarthDoc European Association of Geoscientists and Engineers Database: Amsterdam, The Nederlands, 2017.

66. Krakowska, P.; Puskarczyk, E.; Jędrychowski, M.; Habrat, M.; Madejski, P. Innovative characterization of tight sandstones from Paleozoic basins in Poland using X-ray computed tomography supported by nuclear magnetic resonance and mercury porosimetry. J. Pet. Sci. Eng. 2018, 166, 389-405. [CrossRef]

67. Krakowska, P.; Madejski, P. Research on Fluid Flow and Permeability in Low Porous Rock Sample Using Laboratory and Computational Techniques. Energies 2019, 12, 4684. [CrossRef]

68. Chaudhary, K.; Cardenas, M.B.; Deng, W.; Bennett, P.C. Pore geometry effects on intrapore viscous to inertial flows and on effective hydraulic parameters. Water Resour. Res. 2013, 49, 1149-1162. [CrossRef]

69. Handwerger, D.; Suarez-Rivera, R.; Vaughn, K.; Keller, J. Improved Petrophysical Core Measurements on Tight Shale Reservoirs Using Retort and Crushed Samples. In Proceedings of the SPE Annual Technical Conference and Exhibition, Denver, CO, USA, 30 October-2 November 2011; SPE: Richardson, TX, USA, 2011; pp. 1-19. [CrossRef]

70. Suarez-Rivera, R.; Chertov, M.; Willberg, D.; Green, S.; Keller, J. Understanding Permeability Measurements in Tight Shales Promotes Enhanced Determination of Reservoir Quality. In Proceedings of the SPE Canadian Unconventional Resources Conference, Calgary, AB, Canada, 30 October-1 November 2012; SPE: Richardson, TX, USA, 2012; pp. 1-13.

71. TIBCO Software, Statistica Help; On-line version; TIBCO: Krakow, Poland, 2017.

72. Freund, R.; Wilson, W.; Sa, P. Regression Analysis, 2nd ed.; Elsevier; Academic Press: London, UK, 2006.

73. Mahdaviara, M.; Rostami, A.; Keivanimehr, F.; Shahbazi, K. Accurate determination of permeability in carbonate reservoirs using Gaussian Process Regression. J. Pet. Sci. Eng. 2021, 196, 107807. [CrossRef]

74. Helton Rios, E.; de Oliveira Ramos, P.F.; de França Machado, V.; Chaves Stael, G.; de Vasconcellos Azeredo, R.B. Modeling rock permeability from NMR relaxation data by PLS regression. J. App. Geophys. 2011, 75/4, 631-637. [CrossRef]

75. Garcia, X.; Akanji, L.T.; Blunt, M.J.; Matthai, S.K.; Latham, J.P. Numerical study of the effects of particle shape and polydispersity on permeability. Phys. Rev. E 2009, 80, 021304. [CrossRef] 